\title{
TAXONOMIC DIFFERENTIATION OF IBERIAN KNAPWEEDS (CENTAUREA SECTS. JACEA AND LEPTERANTHUS, ASTERACEAE) AND GENETIC ISOLATION OF INFRASPECIFIC FLORAL MORPHOTYPES ${ }^{1}$
}

\author{
Itziar Arnelas, ${ }^{2,3}$ Ernesto Pérez-Collazos,, 45 \\ Juan A. Devesa, ${ }^{2}$ Antonio J. Manzaneda,${ }^{6}$ and \\ Pilar Catalan ${ }^{4,5,7}$
}

\section{Abstract}

The taxonomic boundaries of Centaurea L. species and infraspecific taxa are often blurred by hybridizations. However, counterbalancing genetic isolation contributes to maintaining taxonomic limits and fostering rapid speciation processes. Radiant (R) and non-radiant (NR) capitula are two major floral morphs present in Centaurea. However, it is unclear how gene flow affects the distribution of floral morphotypes across populations and taxa. We have investigated the taxonomic differentiation and potential effect of genetic isolation in R and NR populations of Iberian Centaurea sects. Jacea (Mill.) Pers. ex Dumort. and Lepteranthus (Neck. ex DC.) Dumort. A total of 510 individuals from 58 populations (12 taxa) were analyzed using 165 amplified fragment length polymorphism (AFLP) markers. Genetic diversity and structure parameters were estimated at the taxon, population, and floral morphotypic levels. We tested whether there was correlation between population pairwise fixation index (Fst) genetic distances and the inbreeding coefficient (Fis), taken as a surrogate of reproductive isolation between the R and NR morphotypes of each group, and also taking into account geographic distances, using distance-based redundancy analysis (dbRDA). We also performed isolation by distance (IBD) tests between different floral morphotypes, aiming to infer the impact of genetic isolation on evolutionary and taxonomic divergence of the individuals. The taxa of Centaurea sects. Jacea and Lepteranthus constitute independent evolutionary lineages. Most of the detected genetic clusters match the taxonomic circumscription proposed in our most recent treatments. Genetic diversity was highest in C. debeauxii Godr. \& Gren. subsp. debeauxii and subsp. grandiflora (Gaudin ex Schübl. \& G. Martens) Devesa \& Arnelas and in C. jacea L. subsp. angustifolia (DC.) Gremli (R) and lowest in C. nevadensis Boiss. \& Reut. (NR) within the Centaurea sect. Jacea clade, whereas it was highest in C. linifolia L. within the Centaurea sect. Lepteranthus clade. Population-level dbRDA tests did not detect a significant correlation of $\mathrm{R}$ versus NR genetic distances and Fis values in any of the studied cases; by contrast, they detected significant correlation with longitude (C. jacea subsp. angustifolia, $C$. debeauxii, C. linifolia-C. stuessyi Arnelas, Devesa \& E. López) or latitude (C. nigra L.). IBD analysis at the individual level showed that, in addition to geography, other morphotype-related factors may affect the genetic differentiation of $\mathrm{R}$ versus NR morphs in $C$. nigra, C. debeauxii, and C. linifolia-C. stuessyi. These results suggest that the fixation of the different morphs within the same taxon or group may be explained by geographic isolation, though we could not discount other potential unknown factors that could have contributed to microspeciation in these recently divergent populations, which originated only several thousands of years ago.

Key words: amplified fragment length polymorphism, Asteraceae, Centaurea, floral morphs, gene flow barriers, population genetics, taxonomy.

1 We thank J. Seco and F. Bogonez for their help during the 2006-2009 field collection trips and Luis Cayuela for fruitful discussion on the potential scenarios of genetic differentiation of floral morphotypes. This work was supported by the Spanish Ministry of Economy and Competitiveness research project grants CGL2005-05471-C04-02, CGL2008-02982-C03-0, CGL200908223-E, and CGL2009-08223-E/BOS. I. A. was funded by a Spanish Ministry of Science and Innovation Ph.D. FPI fellowship. E. P. and P. C. were partially funded by a Bioflora research team grant co-funded by the Spanish Aragón Government and the European Social Fund.

2 Departamento de Botánica, Ecología y Fisiología Vegetal, Facultad de Ciencias, Universidad de Córdoba, Campus de Rabanales, Edificio José Celestino Mutis, Ctra. de Madrid km. 396, 14071 Córdoba, Spain. itziarnelas2@gmail.com, bvldealj@ uco.es.

3 Current address: Herbario HUTPL, Departamento de Ciencias Biológicas, Universidad Técnica Particular de Loja, San Cayetano Alto s/n. CP 11-01-608 Loja, Ecuador. iarnelas@utpl.edu.ec.

${ }^{4}$ Departamento de Ciencias Agrarias y del Medio Natural, Escuela Politécnica Superior de Huesca, Universidad de Zaragoza, Carretera de Cuarte s/n. CP 22071 Huesca, Spain. ernextop@unizar.es, pcatalan@unizar.es.

5 Grupo de Bioquímica, Biofísica y Biología Computacional (BIFI, UNIZAR), Unidad Asociada al CSIC, Zaragoza E-50059, Spain.

6 Departamento de Biología Animal, Biología Vegetal y Ecología, Universidad de Jaén, Campus de las Lagunillas s/n, Jaén E-23071, Spain.

7 Institute of Biology, Tomsk State University, Tomsk 634050, Russia.

Author for correspondence: itziarnelas2@gmail.com 
Centaurea L. is a highly diversified genus of the Asteraceae family. In its current circumscription it comprises nearly 250 species (Susanna \& GarcíaJacas, 2007) distributed mainly in Eurasia, showing a large representation in the Mediterranean and the IranoTuranian regions. Species of the genus show two types of capitula, discoid and radiant. Discoid capitula are composed only of fertile hermaphrodite disk florets, whereas radiant capitula are composed of fertile hermaphrodite disk florets and enlarged peripheral and actinomorphic or slightly actinomorphic neuter florets (Devesa et al., 2014; Devesa, 2016, Fig. 1). Several ploidy levels have been reported in species of Centaurea sects. Jacea (Mill.) Pers. ex Dumort. and Lepteranthus (Neck. ex DC.) Dumort. (Arnelas \& Devesa, 2010), ranging from diploids to hexaploids. Diploids are predominant in Centaurea sect. Lepteranthus, whereas tetraploids are more abundant in Centaurea sect. Jacea. Previous taxonomic studies also detected several populations of putative hybrid origin, involving species in Centaurea sect. Jacea (e.g., Centaurea $\times$ decipiens Thuill pro sp.; Arnelas \& Devesa, 2011) and one species of suspected hybrid origin within Centaurea sect. Lepteranthus (C. stuessyi Arnelas, Devesa \& E. López; Arnelas et al., 2013). Recent phylogenetic studies have demonstrated that Centaurea sects. Jacea and Lepteranthus, although closely related, belong to different lineages and should be maintained as separate sections (Arnelas et al., 2018). This study also confirmed that the maternal and paternal progenitor species of the allotetraploid C. stuessyi originated from lineages Lepteranthus 1 and 2 of Centaurea sect. Lepteranthus, respectively, and that C. gallaecica (M. Laínz) Arnelas \& Devesa should be segregated from $C$. janeri Graells and placed within Centaurea sect. Jacea. The shape of the bract appendage and presence/absence of the achene pappus have been the main characters used to differentiate species of these two sections (Willkomm, 1865; Dostál, 1976; Arnelas \& Devesa, 2011, 2012; Devesa et al., 2014; Devesa, 2016).

Different studies have indicated the existence of floral morphological variability both within and between species of Centaurea sects. Jacea and Lepteranthus; some individuals present a radiant capitulum ( $\mathrm{R}$ morphotype hereafter), whereas others present a nonradiant discoid capitulum (NR morphotype hereafter) (Arnelas \& Devesa, 2011, 2012). Similar morphotypic patterns have also been reported in natural and artificially produced individuals of other genera of the daisy family such as Senecio L., Haplopappus Cass., and Helianthus L. (Trow, 1912; Jackson \& Dimas, 1981; Ingram \& Taylor, 1982; Stuessy et al., 1986; Andersson, 2001). The development of ray flowers in Helianthus and Chrysanthemum L. is under genetic control of the CYCLOIDEA (CYC)-type genes (Chapman et al., 2008,
2012; Huang et al., 2016). For example, studies of gene expression in sunflower (Helianthus annuus L.) demonstrated how a mutation in the single dominant gene HaCYC2c was determinant for the emergence of floral zygomorphy of typical peripheral ray ligulate florets of radiate capitula (Chapman et al., 2012), whereas studies in Chrysanthemum morifolium Ramat. showed how CmCYC2c was highly upregulated and expressed in petal development of peripheral zygomorphic ray ligulate florets of the same type of capitula (Huang et al., 2016). Zygomorphic flowers have played an important role in angiosperm diversification (Cubas, 2004). In Asteraceae, ray flowers have been shown to be an adaptive morphological feature, enhancing floral attractiveness to pollinators (Stuessy et al., 1986; Comes, 1998; Andersson, 2008; Chapman \& Abbott, 2009), increasing plant-pollinator interaction, and presumably also affecting reproductive isolation (Chapman et al., 2012). The extent of the $\mathrm{R}$ and NR morphotypical variation in the Iberian Centaurea sects. Jacea and Lepteranthus species is considerable (Arnelas \& Devesa, 2011,2012 ). Both morphotypes have been found within populations of the same taxon, and in populations of closely related taxa that grow either in allopatry or in overlapping distribution ranges.

Hypervariable molecular markers have been used successfully to analyze the genetic composition and complexity of several plant groups at both taxon and population levels (García-Jacas et al., 2000; Tremetsberger et al., 2004; Pérez-Collazos \& Catalán, 2006; Pérez-Collazos et al., 2009; Anand et al., 2010). Amplified fragment length polymorphism (AFLP) is a powerful genetic fingerprinting technique (Vos et al., 1995) that has proven to be useful in detecting cryptic taxa (Martínez-Ortega et al., 2004) and separating specific and infraspecific genetic groups (Medrano et al., 2014). Here we have analyzed the specific and infraspecific taxa described in two Centaurea sections from the Iberian Peninsula (Centaurea sect. Jacea: C. debeauxii Godr. \& Gren. subsp. debeauxii and subsp. grandiflora (Gaudin ex Schübl. \& G. Martens) Devesa \& Arnelas, C. jacea subsp. angustifolia (DC.) Gremli, C. nevadensis Boiss. \& Reut., C. nigra L. subsp. nigra and subsp. endressii (Hochst. \& Steud) Arnelas \& Devesa; Centaurea sect. Lepteranthus: C. antennata Dufour subsp. antennata, C. gallaecica, C. janeri subsp. janeri and subsp. babiana M. Laínz, C. linifolia L., C. stuessyi), including $\mathrm{R}$ and $\mathrm{NR}$ populations with overlapping and non-overlapping distribution ranges. Our study has two aims: to circumscribe the taxonomic boundaries of this highly hybridogenous Centaurea clade using AFLP markers; and to test the potential of AFLP markers to characterize and separate the floral $\mathrm{R}$ and NR morphotypes in taxa and populations in Centaurea sects. Jacea and Lepteranthus, focusing on the genetic composition 
of their individuals. Through the analysis of the genetic structure of and distance between species, subspecies, and populations using AFLP markers, and its potential correlation with the occurrence, reproductive isolation, and geographical distribution of the floral morphotypes, we aim to test for the existence of barriers to gene flow in populations of Centaurea taxa, and particularly between $\mathrm{R}$ and NR populations of the same taxon with overlapping distribution ranges, and their potential effects in the fixation of the two floral forms.

\section{Materials And Methods}

\section{PLANT MATERIAL, DNA EXTRACTIONS, AND AFLP ANALYSIS}

A total of 510 individuals from 58 Iberian populations of 12 taxa in Centaurea sects. Jacea and Lepteranthus were included in the study (Fig. 1A-F, Supplementary Table S1). In general, seven to 10 individuals were collected per population (Supplementary Table S2). Voucher specimens from all studied populations were deposited at COFC (Supplementary Table S1). Sampling was designed to represent the main specific and intraspecific lineages of Centaurea sects. Jacea and Lepteranthus in the Iberian Peninsula.

Genomic DNA was extracted from silica gel-dried leaves following the DNeasy Plant Mini Kit protocol (Qiagen, Hilden, Germany). The AFLP technique was carried out according to methods from Vos et al. (1995) with slight modifications. Two primer combinations (E-AAG/M-CAC and E-ACA/M-CTC) were selected from 10 combinations tested in a previous screening. Products were separated in 6\% polyacrylamide gels and silver-stained following Bassam et al. (1991). Repeatability of bands ( $<1 \%$ error) was confirmed using control samples in different gels.

\section{GENETIC DIVERSITY}

AFLP fragments were scored in a binary data matrix of presence/absence. We calculated the number of total fragments $\left(\mathrm{f}_{\mathrm{T}}\right)$, unique bands with a frequency equal to 1 $\left(f_{d t}\right)$, private $\left(f_{e} ;\right.$ unique bands with frequency $\left.<1\right)$, and rare $\left(f_{r}\right.$; frequencies $\left.<0.1\right)$ fragments for populations, floral morphotypes, and taxa. Additional measures of genetic diversity were estimated through the frequencydown-weighted marker index using AFLPdat (DW; Schönswetter \& Tribsch, 2005), and the percentage of polymorphic loci at the $99 \%$ criteria $(99 \% \mathrm{P})$ using Excel (Microsoft Corporation, Redmond, Washington, U.S.A.). We applied the rarefaction method of Petit et al. (1998) to estimate band richness $(\mathrm{Pb})$ and the proportion of polymorphic loci using AFLPdiv (Coart et al., 2005) for standardized sample sizes of three and seven for populations and taxa, respectively. We calculated Nei diversity index $(h)$ using Excel. Bayesian genetic diversity, defined as average panmictic heterozygosity within each population, floral morphotype, and taxon $\left(\mathrm{H}_{\mathrm{s}}\right)$, were computed using Hickory version 1.0.4 (Holsinger \& Lewis, 2003). The AFLP data set was analyzed under the free model that does not assume Hardy-Weinberg equilibrium and is therefore suitable for dominant AFLP markers (Holsinger et al., 2002).

GENETIC RELATIONSHIPS, STRUCTURE, AND ISOLATION AMONG FLORAL MORPHOTYPES

Genetic relationship among all studied individuals was assessed by neighbor-joining clustering methods (NJ; Saitou \& Nei, 1987) using pairwise (Nei \& Li, 1979) genetic distances in NTSYSPC v. 2.11a (Rohlf, 2002). Significance of branches was assessed by bootstrap analysis through 1000 replicates (Felsenstein, 1985). We also estimated genetic relationships among taxa, populations, and floral mophotypes using principal coordinates analyses (PCoA) and minimum spanning tree (MST; Gower \& Ross, 1969). Two- and three-dimensional plots were constructed based on the Nei and Li (1979) distance matrix using NTSYS v. 2.11a.

Genetic structure was analyzed through analysis of molecular variance (AMOVA) using Arlequin 3.11 (Excoffier et al., 2005). Different analyses were conducted using: (1) AMOVA of the entire dataset, considering all populations belonging to the same group; and (2) different hierarchical AMOVAs considering different taxonomic and floral morphotype groupings. The Wright Fst coefficient (Wright, 1951) was obtained using Arlequin 3.11.

Bayesian model-based analysis was performed to infer the genetic structure of populations using STRUCTURE 2.2 (Pritchard et al., 2000; Falush et al., 2007). We imposed an admixture model with correlated allele frequencies for the entire dataset and for different taxonomic partitions that share the same common ancestor in order to estimate the probability ( $\mathrm{LnP}[\mathrm{D}])$ of $\mathrm{K}$ groups or hypothetical populations (Pritchard \& Wen, 2004). We ran the analysis for a range of $\mathrm{K}$ values from one to 50, using a burn-in period of 10,000, and a run length of the Markov chain Monte Carlo (MCMC) of 50,000 with eight interactions using the ad hoc parameter $\Delta \mathrm{K}$ of Evanno et al. (2005) to estimate the rate of change of likelihood values between successive $\mathrm{K}$ values. The $\alpha$ parameter (the admixture proportion of an individual) was inferred from the data with Structure; $\alpha$ values close to zero imply that most individuals derive essentially from one or another ancestral Bayesian group, whereas $\alpha$ values $>1$ imply that most individuals are admixed (Falush et al., 2003). Structure data processing was conducted with STRUCTURE HARVESTER (v. 0.9.94) (Earl \& vonHoldt, 2012), which identifies the optimal $\mathrm{K}$ based on both Ln $\operatorname{Pr}(\mathrm{X} \mid \mathrm{K})$ and $\Delta \mathrm{K}$ (Evanno et al., 2005) statistics. 
Distance-based redundancy analysis (dbRDA; Legendre \& Fortin, 2010) was conducted to examine whether geography or reproductive isolation could explain the population genetic differentiation observed both within and between R and NR floral morphotypes in four study cases where the $\mathrm{R}$ and NR morphs showed fully (C. jacea subsp. angustifolia; Fig. 1A) or partially (C. nigra subsp. nigra and subsp. endressii, C. debeauxii subsp. debeauxii and subsp. grandiflora, and the $C$. linifolia-C. stuessyi complex; Fig. 1B, C) overlapping distribution ranges. We used the inbreeding coefficient index (Fis) as a surrogate for population reproductive isolation within and between morphs. To conduct dbRDA analyses we used pairwise population Fst distances as genetic data, geographic coordinates of the centroid of each population (longitude, latitude) as geographic data, and population Fis values, calculated with Hickory v.1.0.4 (Holsinger et al., 2002) under the full model using default prior values (burn-in set to 50,000 and sampling set to 250,000 ) as reproductive isolation data. DbRDA (marginal test) and conditional dbRDA (i.e., test for each set of variables while controlling for the influences of longitude and latitude included as covariates) analyses were performed with the R package VEGAN (Oksanen et al., 2019) using the capscale function. Statistical significance of the predictors, assigned using multivariate F statistics with 9999 permutations and variance components, were obtained with the anova.cca and RsquareAdj functions within the same package. All statistical analyses were performed with R version 3.4.3 (R Core Team, 2019). In order to evaluate the influence of the predictor variables in the genetic differentiation of the individual morphs, we additionally performed dbRDA and isolation by distance (IBD) tests at the individual level. Because we only had the geographic coordinates of the populations, we arbitrarily established a distance of $5 \mathrm{~m}$ between individuals of the same population that closely reflected the sampling distance. We estimated the individual Fis according to Chybicki et al. (2011) and using the I4A software, which applies a Bayesian method that infers whether two dominant alleles could be identical by descent in the individuals. For the IBD analysis we computed Mantel tests between pairwise Fst genetic distances and geographic distances at individual level with 1000 permutations using the VEGAN (Oksanen et al., 2019) package in the $\mathrm{R}$ software. We plotted the Mantel results of genetic versus geographic distances for the R, NR, and R+NR phenotypes of each study case and adjusted the data with trend lines in order to visualize whether geography or isolation caused by floral morphotype explains the genetic differentiation of the individual morphs. For it, we examined whether the linear trends of the $\mathrm{R}, \mathrm{NR}$, and $\mathrm{R}+\mathrm{NR}$ phenotypes fit some of the following four genetics-versus-geography- versus-floral morphotype evolutionary scenarios: (1) no variation of genetic distances with geographic distances in any of the three trend lines with each of them showing similar genetic variation: neither geography nor phenotype affects the genetic differentiation of the individuals (Supplementary Fig. S1A); (2) no variation of genetic distances with geographic distances in any of the three trend lines, but the $\mathrm{R}+\mathrm{NR}$ line showing higher genetic variation than the separate $R$ and NR lines: phenotype and not geography affects the genetic differentiation of the individuals (Supplementary Fig. S1B); (3) variation of genetic distances with geographic distances in all three trend lines with each of them showing similar genetic variation: geography and not phenotype affects the genetic differentiation of the individuals (Supplementary Fig. S1C); and (4) variation of genetic distances with geographic distances in all three trend lines with the $\mathrm{R}+\mathrm{NR}$ line showing higher genetic variation than the separate $\mathrm{R}$ and $\mathrm{NR}$ lines: both geography and phenotype affect the genetic differentiation of the individuals (Supplementary Fig. S1D).

\section{Results}

\section{GENETIC DIVERSITY IN IBERIAN CENTAUREA SECTS. JACEA AND} LEPTERANTHUS

The AFLP approach generated 165 reproducible fragments in 510 studied individuals. Fingerprinting was high: $98.8 \%$ of the sample profiles were polymorphic. Genetic diversity values for all studied populations are shown in Supplementary Table S2. The highest number of total AFLP fragments was obtained for $\mathrm{Cen}$ taurea jacea subsp. angustifolia $(\mathrm{R})$, C. debeauxii subsp. debeauxii (NR), and C. debeauxii subsp. grandiflora $(\mathrm{R})$ (Table 1). Only one diagnostic fragment was detected in C. nigra subsp. endressii (Table 1). Private fragments were scarce across the studied populations, with a single private band found only in $C$. jacea subsp. angustifolia (R/NR), C. nigra subsp. nigra (NR), and $C$. nevadensis (R/NR). Rare fragments were present in all taxa except in C. nevadensis (NR), C. janeri subsp.janeri and subsp. babiana, and $C$. antennata subsp. antennata (Table 1). Highest DW values were detected in $C$. jacea subsp. angustifolia (R); by contrast, $C$. janeri subsp. janeri (R), C. antennata subsp. antennata, and $C$. nevadensis (NR) showed lowest DW values (Table 1). Percentage of polymorphic loci (99\%P), band richness for a standardized sample size of seven $(\mathrm{Pb} 7)$, proportion of polymorphic loci after rarefaction to seven (PLP[7] $5 \%$ ), Nei genetic diversity $(h)$, and average panmictic heterozygosity $\left(\mathrm{H}_{\mathrm{s}}\right)$ indicated that $C$. debeauxii subsp. debeauxii $(\mathrm{NR})(99 \% \mathrm{P}=80 \% ; \mathrm{Pb}[7]=1.526 ; \mathrm{PLP}[7]$ $\left.5 \%=0.709 ; h=0.69 ; \mathrm{H}_{\mathrm{s}}=0.21\right)$ and $C$. debeauxii 

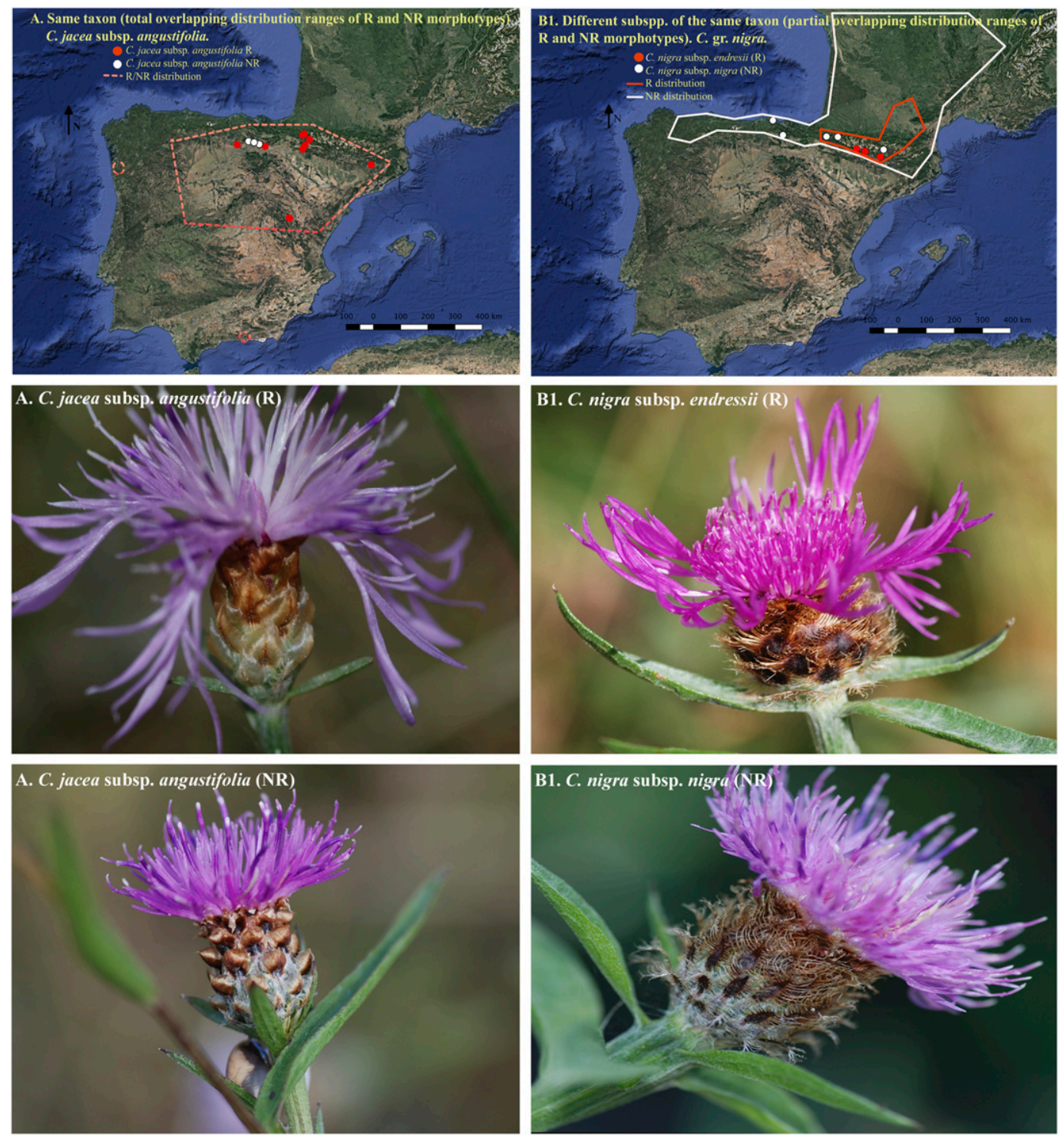

Figure 1, Part 1. Geographical distributions and images of the studied populations and floral radiant (R) and non-radiant (NR) morphotypes of Iberian Centaurea L. sects. Jacea (Mill.) Pers. ex Dumort and Lepteranthus (Neck. ex DC.) Dumort. -A. Different floral morphotypes occurring in the same taxon (overlapping distribution ranges of $\mathrm{R}$ and NR morphotypes): $C$. jacea L. subsp. angustifolia (DC.) Gremli (R, NR). - B. Different floral morphotypes occurring in different subspecies of the same taxon (partially overlapping distribution ranges of R and NR morphotypes). - Bl. Centaurea nigra L. subsp. endressii (Hochst. \& Steud) Arnelas \& Devesa (R) and subsp. nigra (NR). Shading and symbols of taxa and morphotypes are indicated in the figure. Global distributions of taxa are based on Arnelas and Devesa (2011, 2012) and Arnelas et al. (2013). Images: I. Arnelas.

subsp. grandiflora $(\mathrm{R})(99 \% \mathrm{P}=76 \% ; \mathrm{Pb}[7]=$ 1.564; PLP[7]5\% $\left.=0.636 ; h=0.71 ; \mathrm{H}_{\mathrm{s}}=0.21\right)$ are the most diverse taxa (Table 1). Centaurea jacea subsp. angustifolia (R), C. nigra subsp. nigra (NR), and C. linifolia also showed high levels of genetic diversity (Table 1). Lowest genetic diversity levels were detected in C. nevadensis NR $(99 \% \mathrm{P}=17 \%$; $h=0.66 ; \mathrm{H}_{\mathrm{s}}=0.12 ; \mathrm{Pb}[7]=1.174 ; \mathrm{PLP}[7] 5 \%=$ 0.000; Table 1).

Analysis of Centaurea jacea subsp. angustifolia $\mathrm{R}$ and NR morphotypes showed medium values of genetic diversity $(99 \% \mathrm{P}=58 ; \mathrm{Pb}[7]=1.426 ; \mathrm{PLP}[7]$ 

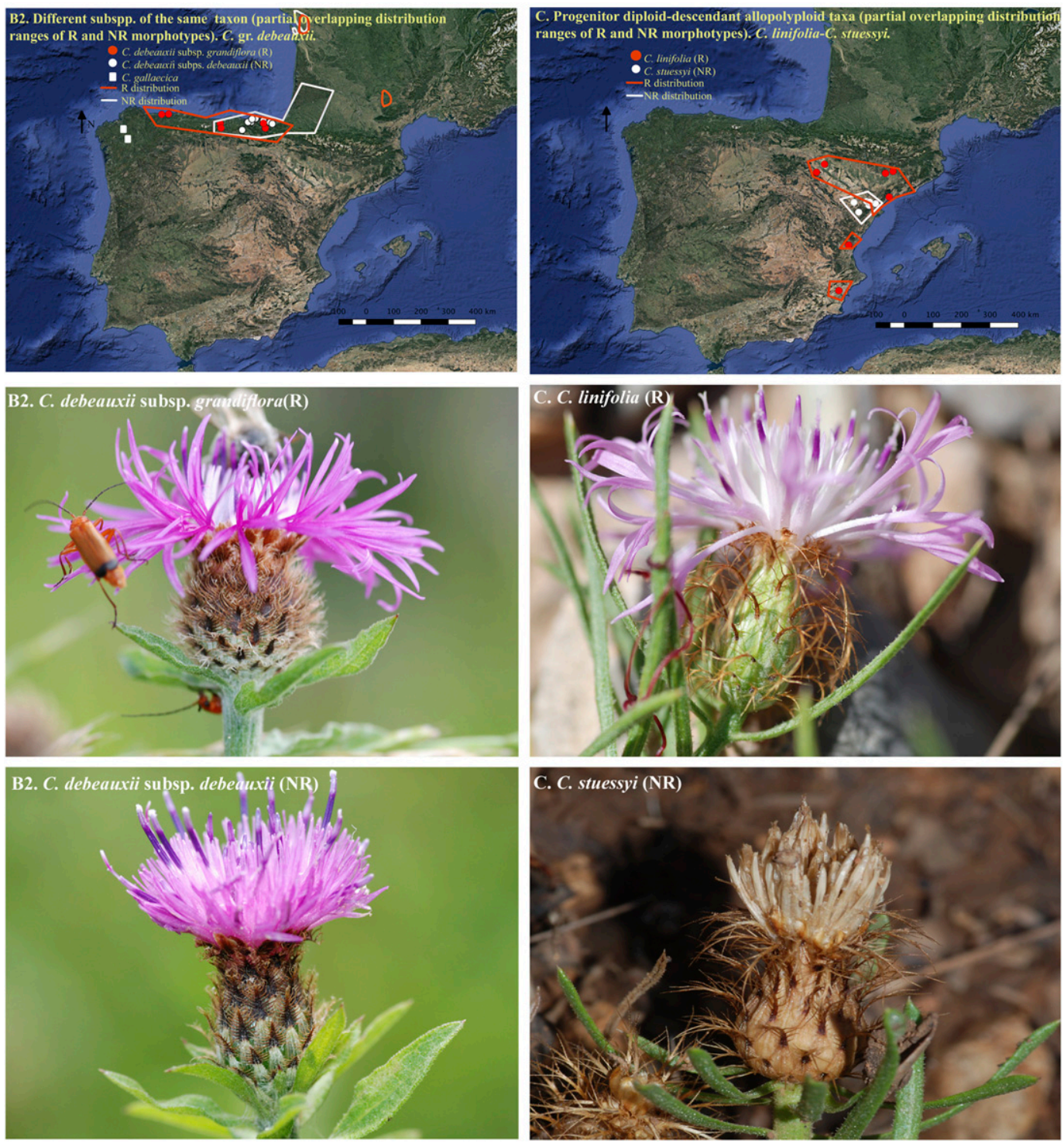

Figure 1, Part 2. Geographical distributions and images of the studied populations and floral radiant (R) and non-radiant (NR) morphotypes of Iberian Centaurea L. sects. Jacea (Mill.) Pers. ex Dumort and Lepteranthus (Neck. ex DC.) Dumort. —B2. Centaurea debeauxii subsp. grandiflora (Gaudin ex Schübl. \& G. Martens) Devesa \& Arnelas (R) and subsp. debeauxii (NR). - C. Different floral morphotypes occurring in progenitor diploid-descendant allopolyploid taxa (partially overlapping distribution ranges of R and NR morphotypes): C. linifolia L. (R) and C. stuessyi Arnelas, Devesa \& E. López (NR). Shading and symbols of taxa and morphotypes are indicated in the figure. Global distributions of taxa are based on Arnelas and Devesa $(2011,2012)$ and Arnelas et al. (2013). Images: I. Arnelas.

$5 \%=0.563 ; h=0.64 ; \mathrm{Hs}=0.17)$ and high values of rare fragments $(\mathrm{fr}=24 ; \mathrm{DW}=78.5)$ in both cases, whereas the NR and R morphotypes of $C$. nevadensis showed low values for rare fragments $(\mathrm{fr}=10 ; \mathrm{DW}=$ 9.61) and genetic diversity $(99 \% \mathrm{P}=28 ; \mathrm{Pb}[7]=1.228$; PLP $[7] 5 \%=0.148 ; h=0.67 ; \mathrm{Hs}=0.12)$; by contrast, the $C$. nevadensis $\mathrm{R}$ morphotypes showed a relatively high value of rare fragments $(\mathrm{fr}=21)$ (Table 1$)$.
GENETIC RELATIONSHIPS, STRUCTURE, AND ISOLATION AMONG TAXA, POPULATIONS, AND FLORAL MORPHOTYPES OF IBERIAN CENTAUREA SECTS. JaCEA AND LEPTERANTHUS

The NJ analysis revealed a high population genetic structure, since most of the sampled individuals clustered into their respective natural populations (Fig. 2A). Genetic circumscription of each taxon is also recovered 

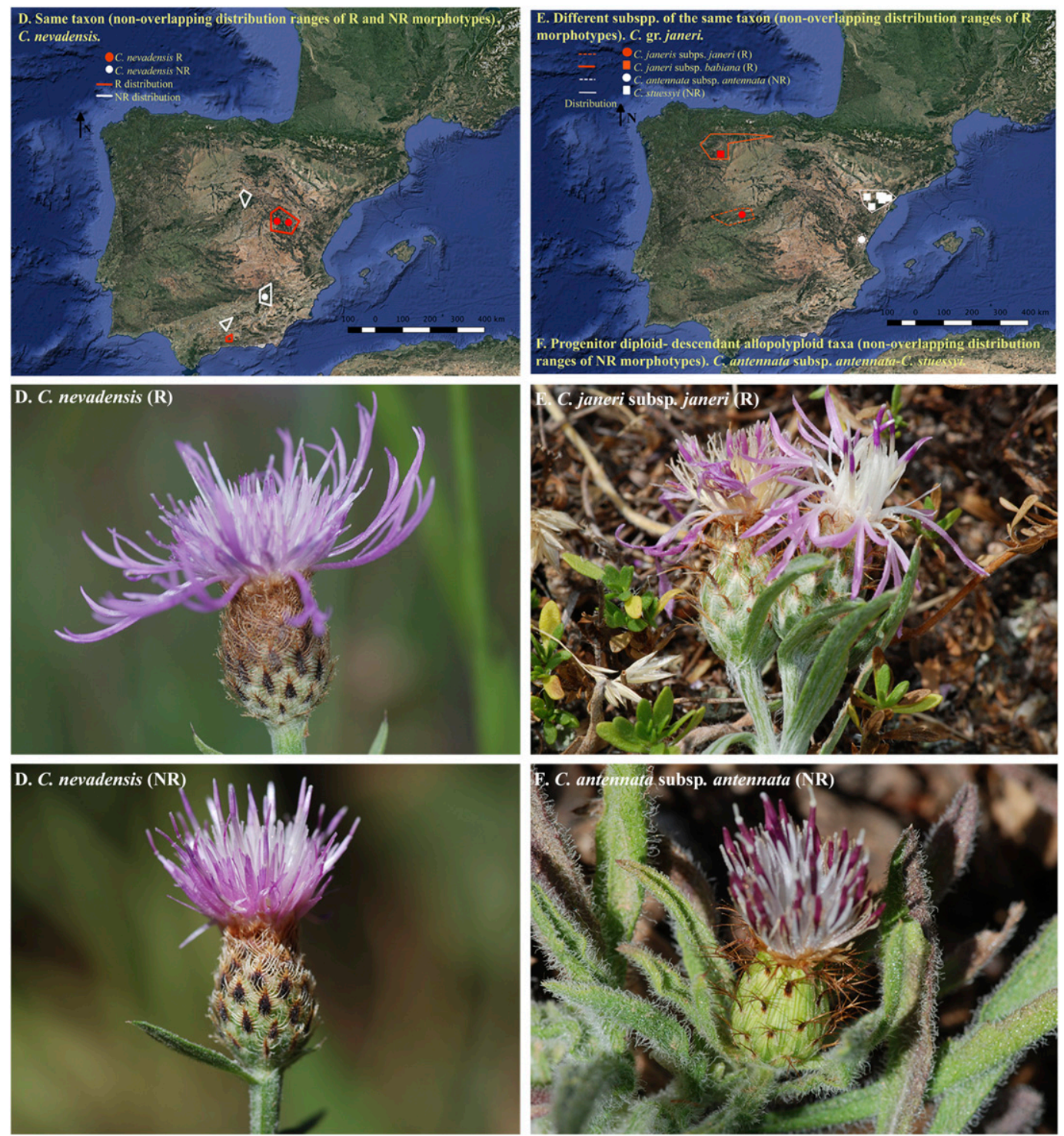

Figure 1, Part 3. Geographical distributions and images of the studied populations and floral radiant $(\mathrm{R})$ and non-radiant (NR) morphotypes of Iberian Centaurea L. sects. Jacea (Mill.) Pers. ex Dumort and Lepteranthus (Neck. ex DC.) Dumort. —D. Different floral morphotypes occurring in the same taxon (non-overlapping distribution ranges of R and NR morphotypes): $C$. nevadensis Boiss. \& Reut. R, NR). - E. Same floral morphotype occurring in different subspecies of the same taxon (non-overlapping distribution ranges of $\mathrm{R}$ and NR morphotypes): C. janeri Graells subsp. janeri $(\mathrm{R})$ and subsp. babiana M. Laínz (NR). - F. Same floral morphotype occurring in progenitor diploid-descendant allopolyploid taxa (non-overlapping distribution ranges of $R$ and $N R$ morphotypes): C. antennata Dufour subsp. antennata (NR) and C. stuessyi (NR). Shading and symbols of taxa and morphotypes are indicated in the figure. Global distributions of taxa are based on Arnelas and Devesa (2011, 2012) and Arnelas et al. (2013). Images: I. Arnelas.

in the NJ phenogram despite the short length and low bootstrap support of branches. A clear genetic divergence was recovered for species belonging to, respectively, Centaurea sects. Jacea and Lepteranthus; the only exception was C. gallaecica (Centaurea sect. Jacea), which clustered with species in Centaurea sect.
Lepteranthus (Fig. 2A). The strong genetic differentiation between sections Jacea and Lepteranthus was also in agreement with the STRUCTURE results (Fig. 2B). Within Centaurea sect. Jacea, the NJ analysis detected four clusters corresponding to (1) C. jacea subsp. angustifolia (R), (2) C. jacea subsp. angustifolia (NR)- 
Table 1. Genetic diversity analysis of the studied Iberian taxa of Centaurea L. sects. Jacea (Mill.) Pers. ex Dumort and Lepteranthus (Neck. ex DC.) Dumort and their floral morphotypes using amplified fragment length polymorphism (AFLP) markers. Taxon name, floral capitulum type (1), ploidy level (2), number of studied populations (3), number of studied individuals (N), number of total fragments $\left(\mathrm{f}_{\mathrm{T}}\right)$, number of diagnostic fragments $\left(\mathrm{f}_{\mathrm{dt}}\right)$, number of private $\left(\mathrm{f}_{\mathrm{e}}\right)$ and rare $\left(\mathrm{f}_{\mathrm{r}}\right)$ fragments, frequency-downweighted marker values index $(\mathrm{DW})$, percentage of polymorphic loci at $99 \%$ criterion $(99 \% \mathrm{P})$, band richness for a standardized sample size after rarefaction for seven individuals per population $(\mathrm{Pb}[7])$ (see Supplementary Table S2), proportion of polymorphic loci after rarefaction for seven individuals per population (PLP[7]5\%) (see Supplementary Table S2), Nei genetic diversity index $(h)$, and average panmictic heterozygosity $\left(\mathrm{H}_{\mathrm{s}}\right)$ data for each taxon.

\begin{tabular}{|c|c|c|c|c|c|c|c|c|c|c|c|c|c|c|}
\hline & & & & & & & & & & $99 \%$ & & $\operatorname{PLP}(7)$ & & \\
\hline Taxon & (1) & $(2)$ & $(3)$ & $\mathrm{N}$ & $\mathrm{f}_{\mathrm{T}}$ & $\mathrm{f}_{\mathrm{dt}}$ & $f_{e}$ & $\mathrm{f}_{\mathrm{r}}$ & DW & $\mathrm{P}$ & $\mathrm{Pb}(7)$ & $5 \%$ & $h$ & $\mathrm{H}_{\mathrm{s}}$ \\
\hline \multicolumn{15}{|l|}{ Centaurea sect. Jacea } \\
\hline C. jacea subsp. angustifolia & $(\mathrm{R})$ & $(4 x)$ & (10) & 93 & 160 & 0 & 1 & 29 & 141.04 & 73 & 1.505 & 0.691 & 0.65 & 0.21 \\
\hline C. jacea subsp. angustifolia & $(\mathrm{NR})$ & $(4 x)$ & (3) & 30 & 117 & 0 & 1 & 20 & 16.27 & 43 & 1.347 & 0.436 & 0.63 & 0.14 \\
\hline C. jacea s.l. & & & & 123 & 152 & 0 & 2 & 24 & 78.50 & 58 & 1.426 & 0.563 & 0.64 & 0.17 \\
\hline C. nigra subsp. nigra & $(\mathrm{NR})$ & $(2 x, 4 x)$ & (5) & 45 & 133 & 0 & 1 & 14 & 24.05 & 62 & 1.496 & 0.630 & 0.63 & 0.19 \\
\hline C. nigra subsp. endressii & $(\mathrm{R})$ & $(4 x)$ & (3) & 30 & 121 & 1 & 0 & 16 & 46.81 & 47 & 1.356 & 0.321 & 0.63 & 0.15 \\
\hline C. debeauxii subsp. debeauxii & $(\mathrm{NR})$ & $(4 x)$ & (10) & 89 & 141 & 0 & 0 & 28 & 34.43 & 80 & 1.526 & 0.709 & 0.69 & 0.21 \\
\hline $\begin{array}{l}\text { C. debeauxii subsp. } \\
\text { grandiflora }\end{array}$ & $(\mathrm{R})$ & $(4 x)$ & (6) & 54 & 136 & 0 & 0 & 31 & 15.62 & 76 & 1.564 & 0.636 & 0.71 & 0.21 \\
\hline C. nevadensis & $(\mathrm{R})$ & $(2 x)$ & (3) & 21 & 103 & 0 & 1 & 21 & 13.45 & 39 & 1.280 & 0.297 & 0.68 & 0.12 \\
\hline C. nevadensis & $(\mathrm{NR})$ & $(2 x)$ & (1) & 7 & 79 & 0 & 1 & 0 & 5.77 & 17 & 1.176 & 0.000 & 0.66 & 0.12 \\
\hline C. nevadensis s.l. & & & & 28 & 117 & 0 & 2 & 10 & 9.61 & 28 & 1.228 & 0.148 & 0.67 & 0.12 \\
\hline C. gallaecica & $(\mathrm{NR})$ & $(6 x)$ & (2) & 20 & 111 & 0 & 0 & 12 & 8.75 & 36 & 1.294 & 0.188 & 0.61 & 0.14 \\
\hline \multicolumn{15}{|l|}{ Centaurea sect. Lepteranthus } \\
\hline C. janeri subsp. janeri & $(\mathrm{R})$ & $(4 x)$ & (1) & 9 & 97 & 0 & 0 & 0 & 3.10 & 18 & 1.360 & 0.036 & 0.54 & 0.13 \\
\hline C. janeri subsp. babiana & $(\mathrm{R})$ & $(4 x)$ & (1) & 9 & 99 & 0 & 0 & 0 & 7.27 & 23 & 1.408 & 0.073 & 0.57 & 0.14 \\
\hline $\begin{array}{l}\text { C. antennata subsp. } \\
\text { antennata }\end{array}$ & $(\mathrm{R})$ & $(2 x)$ & (1) & 9 & 95 & 0 & 0 & 0 & 4.77 & 24 & 1.234 & 0.061 & 0.61 & 0.13 \\
\hline C. linifolia & $(\mathrm{R})$ & $(2 x)$ & (6) & 53 & 131 & 0 & 0 & 24 & 18.08 & 68 & 1.496 & 0.564 & 0.70 & 0.20 \\
\hline C. stuessyi & $(\mathrm{NR})$ & $(4 x)$ & (6) & 41 & 127 & 0 & 0 & 24 & 15.13 & 56 & 1.410 & 0.503 & 0.64 & 0.17 \\
\hline
\end{tabular}

NR, non-radiant; R, radiant.

C. nigra subsp. endressii, (3) C. nigra subsp. nigra-C. debeauxii subsp. debeauxii, and (4) C. debeauxii subsp. grandiflora-C. nevadensis (R, NR). Unexpectedly, the NJ analysis showed the individuals of $C$. debeauxii subsp. debeauxii and subsp. grandiflora to be more similar genetically to those of $C$. nigra subsp. nigra and C. nevadensis than to each other (Fig. 2A). Within Centaurea sect. Lepteranthus, the NJ analysis recovered two clusters that comprised (1) C. antennata subsp. antennata, C. stuessyi (STU 06, 02), C. janeri, and $C$. gallaecica (Centaurea sect. Jacea), and (2) C. linifolia and C. stuessyi (STU 01, 03, 05, 04) (Fig. 2A). These results were also congruent with the STRUCTURE results, except that some individuals of $C$. stuessyi (STU 01, 03, 05, 04) were admixed with those of $C$. linifolia (Fig. 2A). Centaurea jacea subsp. angustifolia $\mathrm{R}$ and NR morphotypes showed some segregation in two close but separate groups. Also, the NJ analysis showed morphotype segregation in the two subspecies of $C$. debeauxii (subsp. debeauxii NR, subsp. grandiflora $\mathrm{R}$ ) and $C$. nigra (subsp. nigra NR, subsp. endressii R), respectively. Two populations of $C$. stuessyi (STU 06, 02) clustered with $C$. antennata subsp. antennata and four populations with $C$. linifolia (R) (Fig. 2A).

$\mathrm{PCoA}$ analyses revealed similar genetic relationships among the studied individuals (Fig. 3, Supplementary Table S3). Two groups coincident with species belonging, respectively, to Centaurea sect. Jacea and Centaurea sect. Lepteranthus plus C. gallaecica, separated along axis 1 , which accumulated $7.52 \%$ of variance (Fig. 3A, Supplementary Table S3). MST analysis recovered a high cohesiveness within each group, with only a single intergroup connection found between $C$. jacea subsp. angustifolia (sect. Jacea) and C. antennata subsp. antennata (sect. Lepteranthus) (Fig. 3A). Separate PCoA analysis for individuals of Centaurea sect. Jacea showed segregation of the C. jacea subsp. angustifolia group from the C. nigra (subsp. nigra and subsp. endressii) plus $C$. debeauxii (subsp. debeauxii and subsp. grandiflora) group in the 3D plot, which accumulated $18.50 \%, 13.30 \%$, and $7.40 \%$ of variance in its three main axes (Fig. 3B). Noticeably, intraspecific PCoA analysis of $C$. jacea subsp. angustifolia recovered a separation of $\mathrm{R}$ and NR morphotypic 


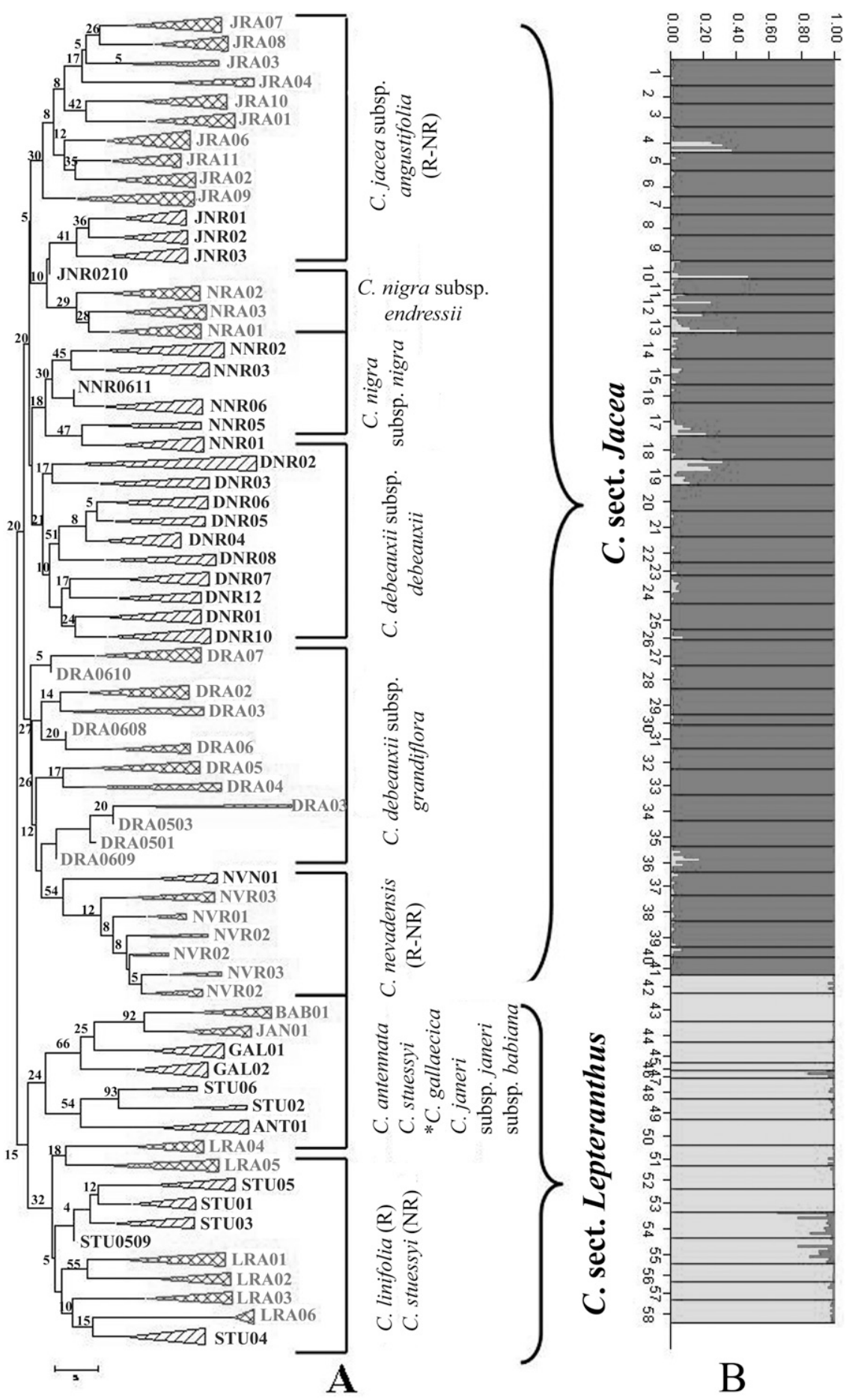

Figure 2. Genetic relationship among the studied populations and floral radiant $(\mathrm{R})$ and non-radiant $(\mathrm{NR})$ morphotypes of taxa of Iberian Centaurea L. sects. Jacea (Mill.) Pers. ex Dumort and Lepteranthus (Neck. ex DC.) Dumort based on amplified fragment length polymorphism (AFLP) data sorted by taxonomic rank and morphotypes. - A. Neighbor-joining (NJ) analysis of 510 studied individuals. -B. Genetic structure of the studied samples inferred by STRUCTURE for an optimal K = 2. Floral morphotypes of radiant (R) and non-radiant (NR) discoid capitula are indicated in gray and black colors, respectively, in the NJ phenogram of Figure 2A. Numbers on branches indicate bootstrap support values. The asterisk indicates that C. gallaecica (M. Laínz) Arnelas \& Devesa belongs to Centaurea sect. Jacea. 

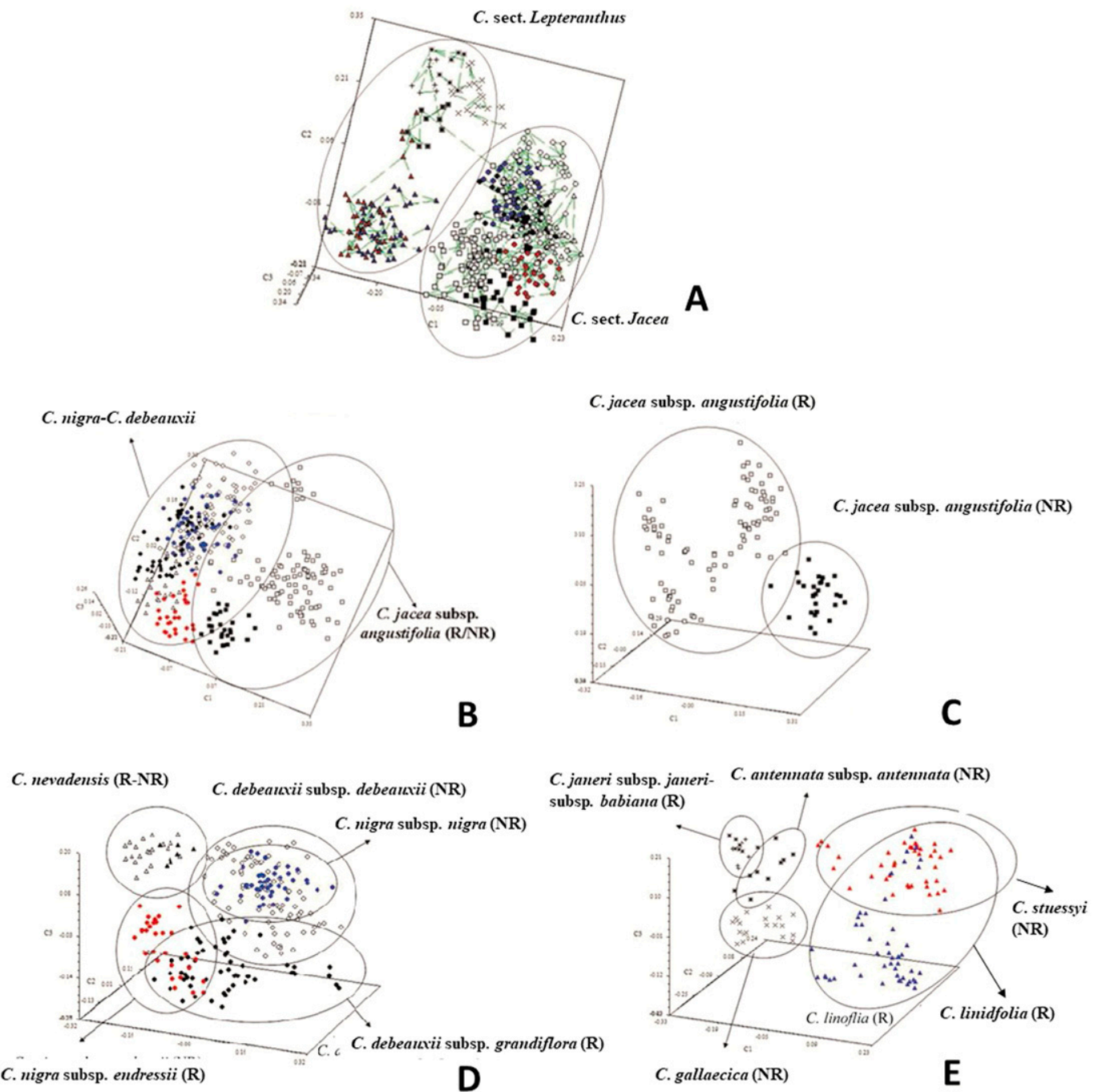

Figure 3. Genetic relationship among 510 studied individuals of Iberian Centaurea L. sects. Jacea (Mill.) Pers. ex Dumort and Lepteranthus (Neck. ex DC.) Dumort taxa based on amplified fragment length polymorphism (AFLP) data inferred by principal coordinates analysis (PCoA) and minimum spanning tree (MST) analyses. - A. Centaurea sects. Jacea and Lepteranthus groups. -B. Centaurea jacea L. subsp. angustifolia (DC.) Gremli (radiant [R]-non-radiant [NR]) and Centaurea gr. nigra L.-Centaurea gr. debeauxii Godr. \& Gren. groups. - C. Centaurea jacea subsp. angustifolia (R) and C. jacea subsp. angustifolia (NR) groups. -D. Centaurea gr. nigra-Centaurea gr. debeauxii-C. nevadensis Boiss. \& Reut. -E. Centaurea antennata Dufour subsp. antennata, C. linifolia L., C. stuessyi Arnelas, Devesa \& E. López, Centaurea gr. janeri Graells, and C. gallaecica (M. Laínz) Arnelas \& Devesa*. *Classified within Centaurea sect. Jacea according to Arnelas and Devesa (2012).

groups, also with high percentage of accumulated variance in the three main axes (29.23\%) (Fig. 3C, Supplementary Table S3). Independent PCoA analysis of $C$. nigra-C. debeauxii-C. nevadensis showed genetic differences between the species and all their taxa (C. nigra subsp. nigra and $C$. nigra subsp. endressii, C. debeauxii subsp. debeauxii, and C. debeauxii subsp. grandiflora) but with some overlapping between the respective C. debeauxii subsp. debeauxii-C. nigra subsp. nigra, and C. debeauxii subsp. grandiflora-C. nigra subsp. endressii plots (Fig. 3D, Supplementary Table S3). However, no segregation was observed for $C$. nevadensis $\mathrm{R}$ and $\mathrm{NR}$ morphotypes. Individual PCoA analysis of Centaurea sect. Lepteranthus plus C. gallaecica (Centaurea sect. Jacea) showed the segregation of the $C$. linifolia-C. stuessyi group from the $C$. antennata subsp. antennata-C. janeri-C. gallaecica group along the first axis that accumulated $16.00 \%$ of variance (Fig. 3E, Supplementary Table S3). The first three axes (31.70\% variance) of this plot segregated C. janeri (C. janeri subsp. janeri and subsp. babiana), C. 
Table 2. Genetic structure of the studied Iberian taxa of Centaurea L. sects. Jacea (Mill.) Pers. ex Dumort and Lepteranthus (Neck. ex DC.) Dumort using amplified fragment length polymorphism (AFLP) markers analyzed through analysis of molecular variance (AMOVA) for different taxonomic and floral morphotype groupings.

\begin{tabular}{|c|c|c|c|}
\hline Grouping & Gl & $\%$ Var & Fst \\
\hline \multicolumn{4}{|c|}{ A. One group with all populations } \\
\hline Among populations & 58 & 59.05 & \multirow[t]{2}{*}{$0.59(P<0.001)$} \\
\hline Within populations & 453 & 40.95 & \\
\hline \multicolumn{4}{|c|}{ B. 12 groups: according to taxonomic treatment } \\
\hline \multicolumn{4}{|c|}{ [JRA/JNR]-[NNR]-[NRA]-[DNR]- [DRA]-[NVR/NVN]-[GAL]-[JAN]- [BAB]-[LRA]-[STU]-[ANT] } \\
\hline Among groups & 11 & 21.52 & \multirow[t]{3}{*}{$0.60(P<0.001$} \\
\hline Among populations & 46 & 38.71 & \\
\hline Within populations & 441 & 39.77 & \\
\hline \multicolumn{4}{|c|}{ C. 14 groups: considering both taxa and R-NR morphotypes as separate groups } \\
\hline \multicolumn{4}{|c|}{ [JR]-[JNR]-[NNR]-[NRA]-[DNR]- [DR]-[NVR]-[NVN]-[GAL]-[JAN]-[BAB]-[LRA]-[STU]-[ANT] } \\
\hline Among groups & 13 & 23.45 & \multirow[t]{3}{*}{$0.60(P<0.001)$} \\
\hline Among populations & 44 & 36.64 & \\
\hline Within populations & 441 & 39.91 & \\
\hline \multicolumn{4}{|c|}{ D. One group: Centaurea sect. Lepteranthus } \\
\hline Among populations & 16 & 65.44 & \multirow[t]{2}{*}{$0.65(P<0.001)$} \\
\hline Within populations & 119 & 34.56 & \\
\hline \multicolumn{4}{|c|}{ E. One group: Centaurea sect. Jacea } \\
\hline Among populations & 12 & 53.00 & \multirow[t]{2}{*}{$0.53(P<0.001)$} \\
\hline Within populations & 110 & 47.00 & \\
\hline
\end{tabular}

ANT, Centaurea antennata Dufour subsp. antennata (NR); BAB, C. janeri Graells subsp. babiana M. Laínz (R); DNR, C. debeauxii Godr. \& Gren. subsp. debeauxii (NR); DRA, C. debeauxii subsp. grandiflora (Gaudin ex Schübl. \& G. Martens) Devesa \& Arnelas (NR); Fst, fixation index; GAL, C. gallaecica (M. Laínz) Arnelas \& Devesa (NR); gl, grade of freedom; JAN, C. janeri subsp. janeri (R); JNR, C. jacea L. subsp. angustifolia (DC.) Gremli (NR); JRA, C. jacea subsp. angustifolia (R); LRA, C. linifolia L. (R); NNR, C. nigra L. subsp. nigra (NR); NR, non-radiant; NRA, C. nigra subsp. endressii (Hochst. \& Steud) Arnelas \& Devesa (R); NVN, C. nevadensis Boiss. \& Reut. (NR); NVR, C. nevadensis (R); R, radiant; STU, C. stuessyi Arnelas, Devesa \& E. López (NR); \%Var, percentage of variation.

gallaecica, and C. antennata subsp. antennata, and to a lesser extent $C$. linifolia from $C$. stuessyi (Fig. 3E).

AMOVA analysis revealed that $59.05 \%$ of the total genetic variation was found among populations (Table 2A), suggesting a high genetic divergence of Centaurea sects. Jacea and Lepteranthus. Hierarchical AMOVA of the 12 studied taxa revealed $21.52 \%$ and $38.71 \%$ of the total variation among taxa and among populations, respectively (Table 2B). Hierarchical AMOVA of 14 groups considering floral morphotypes revealed an increase of genetic structure among groups (23.45\%), with a variation among populations of $36.64 \%$ (Table 2C). Separate AMOVA analysis of taxa belonging to Centaurea sect. Jacea and Centaurea sect. Lepteranthus showed $53.00 \%$ and $65.44 \%$ of the total genetic variation distributed among populations, respectively (Table $2 \mathrm{D}, 2 \mathrm{E}$ ).

AFLP Bayesian analysis conducted with STRUCTURE found the highest $\mathrm{LnP}(\mathrm{D})$ and $\Delta \mathrm{K}$ values for $\mathrm{K}=2(P<0.001)$, revealing two optimal hypothetical groups congruent with Centaurea sect. Jacea and Centaurea sect. Lepteranthus (plus C. gallaecica) (Fig. 2B). The $\alpha$ value was 0.046 , indicating a clear assignment of the individual plant's membership to each genetic group. Genetic structure analysis of Centaurea sect. Jacea showed the highest values of $\Delta \mathrm{K}$ for $\mathrm{K}=2$, where $C$. jacea subsp. angustifolia (R, NR) was segregated from C. nigra-C. debeauxii (Fig. 4A). Independent analysis of floral morphotypes of $C$. jacea subsp. angustifolia (R, NR; Fig. 4B) recovered a highest value of $\Delta \mathrm{K}$ for $\mathrm{K}=2$, corresponding to a genetic group composed of intermixed $\mathrm{R}$ and NR populations (JNR 01, 02, 03; JRA 02, 06, 09, and 11), and a second group formed only by R populations (JRA 01, 03, 04, 07, 08, and 10). Separate analysis of C. nigra-C. debeauxii-C. nevadensis showed the highest value of $\Delta \mathrm{K}$ for $\mathrm{K}=2$, revealing the segregation of the two abundant species (C. nigra subsp. nigra and subsp. endressii vs. $C$. debeauxii subsp. debeauxii and subsp. grandiflora), though two populations of $C$. debeauxii ( $C$. debeauxii subsp. debeauxii [DNR10] and $C$. debeauxii subsp. grandiflora [DRA 06]) clustered within the $C$. nigra group (Fig. 4C). Independent analysis of C. nigra-C. debeauxii subsp. debeauxii DNR10-C. debeauxii subsp. grandiflora DRA06 supported the segregation of the two subspecies of $C$. nigra (highest values of $\Delta \mathrm{K}$ for $\mathrm{K}=2$ ), showing the closeness of $C$. nigra subsp. nigra and 


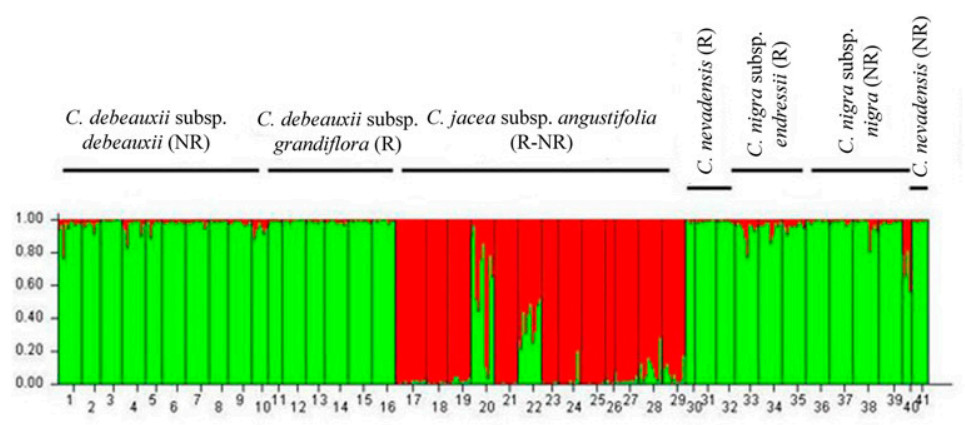

A
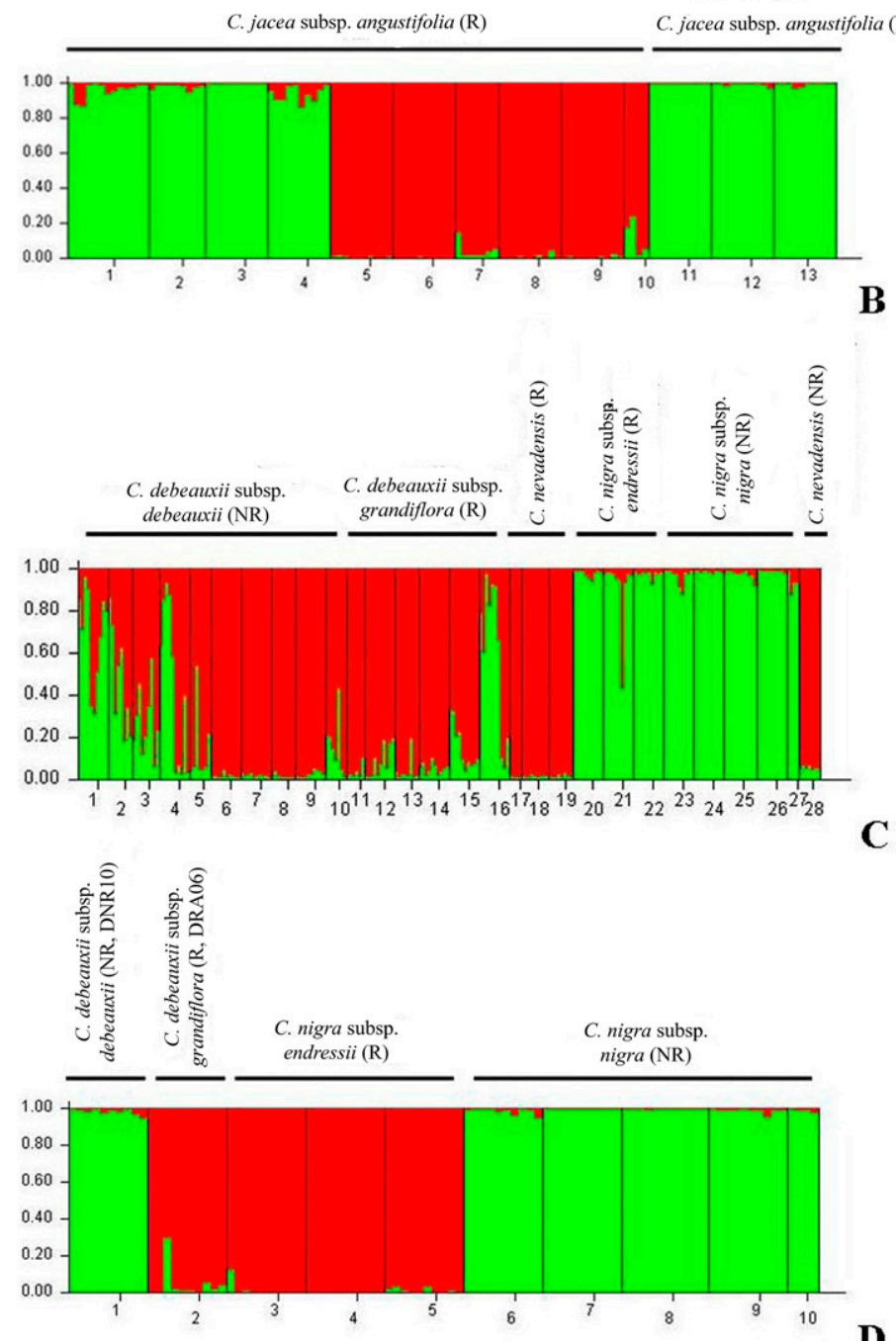

Figure 4. Bayesian genetic structure analysis of the studied individuals of taxa of Iberian Centaurea L. sect. Jacea (Mill.) Pers. ex Dumort based on amplified fragment length polymorphism (AFLP) data inferred by STRUCTURE. —A. Centaurea sect. Jacea . -B. Centaurea jacea L. subsp. angustifolia Gremli R and NR groups. - C. Centaurea nigra L.-C. debeauxii Godr. \& Gren.-C. nevadensis Boiss. \& Reut. groups. - D. Centaurea nigra, C. debeauxii subsp. debeauxii (DNR 10), and C. debeauxii subsp. grandiflora (Gaudin ex Schübl. \& G. Martens) Devesa \& Arnelas (DRA 06) groups. 

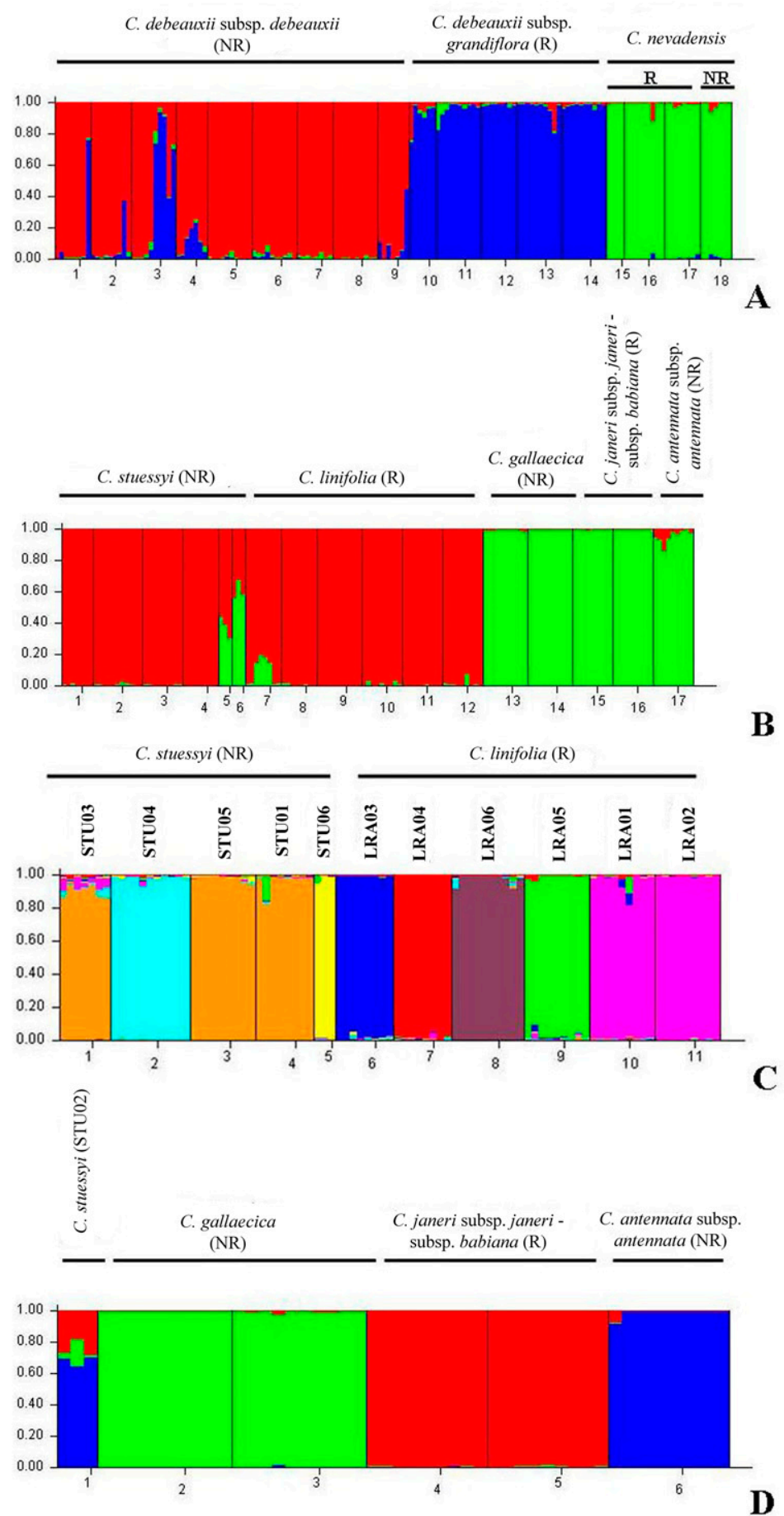

Figure 5. Bayesian genetic structure analysis of the studied individuals of taxa of Iberian Centaurea L. sects. Jacea (Mill.) Pers. ex Dumort and Lepteranthus (Neck. ex DC.) Dumort based on amplified fragment length polymorphism (AFLP) data inferred by STRUCTURE. -A. Centaurea sect. Jacea: C. debeauxii Godr. \& Gren. (excluding DNR 10 and DRA 06) taxa and C. nevadensis Boiss. \& Reut. -B. Centaurea sect. Lepteranthus taxa. - C. Centaurea stuessyi Arnelas, Devesa \& E. López (non-radiant [NR]) (excluding STU 02) and C. linifolia L. (radiant [R]). - D. Centaurea gallaecica (M. Laínz) Arnelas \& Devesa (NR), C. janeri Graells subsp. janeri (R) and subsp. babiana M. Laínz (R), C. antennata Dufour subsp. antennata (NR), and C. stuessyi (STU 02, NR). 
Table 3. Distance-based redundancy analysis (dbRDA) values obtained from marginal tests conducted at population level for each of the Centaurea L. radiant $(\mathrm{R})$, non-radiant $(\mathrm{NR})$, and combined $\mathrm{R}+\mathrm{NR}$ morphotype case studies $($ C. jacea L. subsp. angustifolia (DC.) Gremli, C. nigra L., C. debeauxii Godr. \& Gren., C. linifolia L.-C. stuessyi Arnleas, Devesa \& E. López). Response variable (pairwise Fst genetic distances between populations), predictive reproductive isolation variable (inbreeding coefficient Fis), geographical variables (latitude and longitude). The marginal tests evaluate the potential effect of reproductive isolation (measured as Fis) on genetic distances (Fst) taking into account geographic distances. The dbRDA test was not performed for $C$. jacea subsp. angustifolia NR and C. nigra subsp. endressi (Hochst. \& Steud) Arnelas \& Devesa R cases due to the low number of populations.

\begin{tabular}{|c|c|c|c|c|c|c|c|c|c|c|c|}
\hline \multicolumn{12}{|c|}{ C. jacea subsp. angustifolia } \\
\hline $\mathrm{R}$ & & & & NR & & & & $\mathrm{R}+\mathrm{NR}$ & & & \\
\hline Marginal test & & & & Marginal test & & & & Marginal test & & & \\
\hline Variable & $\mathrm{F}$ & $P$ & $\%$ Var & Variable & $\mathrm{F}$ & $P$ & $\%$ Var & Variable & $\mathrm{F}$ & $P$ & $\%$ Var \\
\hline Fis & 1.97 & 0.242 & & & & & & Fis & 1.22 & 0.190 & \\
\hline Longitude & 1.92 & $0.001 \ddagger$ & 18.2 & & & & & Longitude & 2.52 & $0.001^{\ddagger}$ & 18.27 \\
\hline Latitude & 1.40 & $0.068^{\S}$ & 13.3 & & & & & Latitude & 1.41 & 0.070 & \\
\hline \multicolumn{12}{|c|}{ C. nigra } \\
\hline C. nigra subsp. & endres. & sii $(\mathrm{R})$ & & C. nigra subs! & p. nigra & $(\mathrm{NR})$ & & $\mathrm{R}+\mathrm{NR}$ & & & \\
\hline Marginal test & & & & Marginal test & & & & Marginal test & & & \\
\hline Variable & $\mathrm{F}$ & $P$ & $\%$ Var & Variable & $\mathrm{F}$ & $P$ & $\%$ Var & Variable & $\mathrm{F}$ & $P$ & $\%$ Var \\
\hline Fis & & & & Fis & 0.70 & 0.812 & & Fis & 0.73 & 0.816 & \\
\hline Longitude & & & & Longitude & 0.89 & 0.641 & & Longitude & 0.98 & 0.465 & \\
\hline Latitude & & & & Latitude & 0.94 & 0.541 & & Latitude & 2.29 & $0.037 *$ & 28.7 \\
\hline \multicolumn{12}{|c|}{ C. debeauxii } \\
\hline C. debeauxii su & bsp. $g r$ & andiflora & & C. debeauxii $\mathrm{s}$ & subsp. $d e$ & beauxii & $(\mathrm{NR})$ & $\mathrm{R}+\mathrm{NR}$ & & & \\
\hline Marginal test & & & & Marginal test & & & & Marginal test & & & \\
\hline Variable & $\mathrm{F}$ & $P$ & $\%$ Var & Variable & $\mathrm{F}$ & $P$ & $\%$ Var & Variable & $\mathrm{F}$ & $P$ & $\% \mathrm{Var}$ \\
\hline Fis & 0.63 & 0.840 & & Fis & 0.285 & 0.998 & & Fis & 0.58 & 0.905 & \\
\hline Longitude & 1.68 & 0.143 & & Longitude & 0.984 & 0.441 & & Longitude & 2.40 & $0.006^{\dagger}$ & 12.5 \\
\hline Latitude & 0.89 & 0.585 & & Latitude & 0.836 & 0.637 & & Latitude & 0.63 & 0.880 & \\
\hline \multicolumn{12}{|c|}{ C. linifolia-C. stuessyi } \\
\hline C. linifolia $(\mathrm{R})$ & & & & C. stuessyi (NH & & & & $\mathrm{R}+\mathrm{NR}$ & & & \\
\hline Marginal test & & & & Marginal test & & & & Marginal test & & & \\
\hline Variable & $\mathrm{F}$ & $P$ & $\%$ Var & Variable & $\mathrm{F}$ & $P$ & $\%$ Var & Variable & $\mathrm{F}$ & $P$ & $\%$ Var \\
\hline Fis & 0.82 & 0.72 & & Fis & 0.69 & 0.717 & & Fis & 0.58 & 0.909 & \\
\hline Longitude & 0.11 & 0.447 & & Longitude & 0.74 & 0.641 & & Longitude & 2.41 & $0.004 *$ & 10.4 \\
\hline Latitude & 0.56 & 0.935 & & Latitude & 1.22 & 0.331 & & Latitude & 0.63 & 0.881 & \\
\hline
\end{tabular}

\footnotetext{
$* P<0.05$.

$\dagger P<0.01$.

$\$ P<0.001$.

$\S$ Marginal significance.
}

C. debeauxii subsp. debeauxii DNR10, and of C. nigra subsp. endressii and $C$. debeauxii subsp. grandiflora DRA06 (Fig. 4D). Separate analysis of $C$. debeauxii-C. nevadensis recovered the highest values of $\Delta \mathrm{K}$ for $\mathrm{K}=$ 3 , where each of the three taxa $(C$. debeauxii subsp. debeauxii, C. debeauxii subsp. grandiflora, and C. nevadensis) was assigned to a different genetic group (Fig. 5A).

Genetic structure analysis for Centaurea sect. Lepteranthus plus C. gallaecica showed the highest values of $\Delta \mathrm{K}$ for $\mathrm{K}=2$ (Fig. 5B). The first group contained $C$. linifolia and C. stuessyi (all populations except STU 02), and the second group C.janeri-C. gallaecica-C. antennata subsp. antennata-C. stuessyi (STU 02), with both groups including $\mathrm{R}$ and NR morphotypes. An independent analysis of $C$. linifolia and C. stuessyi (all populations except STU 02) showed the highest values of $\Delta \mathrm{K}$ for $\mathrm{K}=8$ classifying populations into groups without any apparent geographical structure $(\mathrm{K} 1=C$. stuessyi: 
C. jacea subsp. angustifolia $(\mathrm{R})$
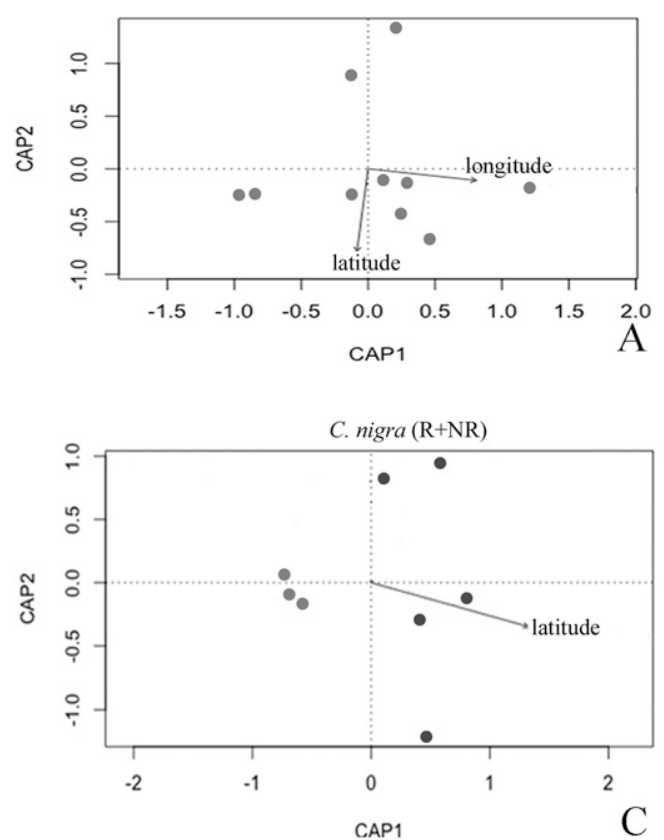

C. jacea subsp. angustifolia $(\mathrm{R}+\mathrm{NR})$
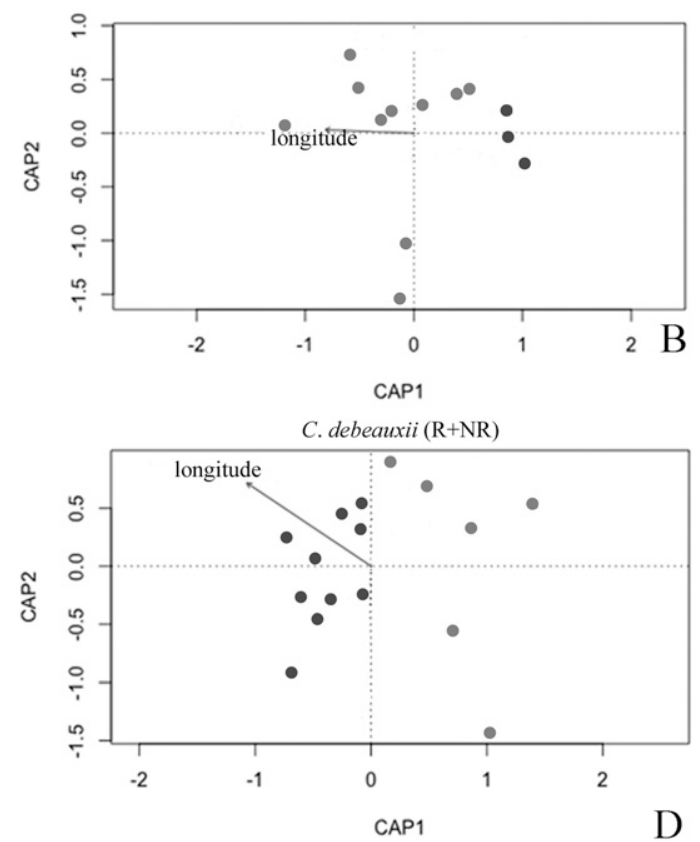

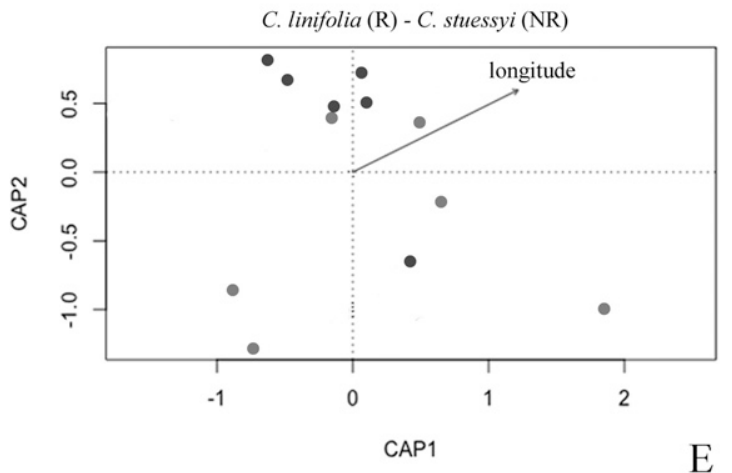

Figure 6. Distance-based redundancy analysis (dbRDA) plots (by multidimensional scaling) showing the position of the studied Centaurea L. radiant (R) (gray dots) and non-radiant (NR) (black dots) populations relative to the two main RDA axes, according to their genetic differentiation (the closer the populations in the plots, the lower the genetic dissimilarity). Significant explanatory variables are depicted as solid vectors (see Table 3). - A. Centaurea jacea L. subsp. angustifolia (DC.) Gremli (R). -B. Centaurea jacea subsp. angustifolia $(\mathrm{R}+\mathrm{NR})$. - C. Centaurea nigra L. $(\mathrm{R}+\mathrm{NR})$. - D. Centaurea debeauxii Godr. \& Gren. $(\mathrm{R}+\mathrm{NR})$. - E. Centaurea linifolia L.-C. stuessyi Arnelas, Devesa \& E. López.

STU 03, 05, 01; K2 = C. stuessyi: STU 04; K3 = C. stuessyi: STU 06; K4 = C. linifolia: LRA 03; K5 $=C$. linifolia: LRA 04; K6 = C. linifolia: LRA 06; K7 =C. linifolia: LRA 05; K8 = C. linifolia: LRA 01, 02; Fig. 5C). A separate analysis for C. janeri-C. gallaecica-C. antennata subsp. antennata-C. stuessyi (STU 02) showed the highest values of $\Delta \mathrm{K}$ for $\mathrm{K}=3$, corresponding to the $C$. stuessyi STU 02-C. antennata subsp. antennata, C. janeri, and C. gallaecica groups (Fig. 5D).
The dbRDA analyses were performed for R, NR, and $\mathrm{R}+\mathrm{NR}$ populations in all four case studies $(C$. jacea subsp. angustifolia, C. nigra, C. debeauxii, C. linifoliaC. stuessyi) except for C. jacea subsp. angustifolia (NR) and $C$. nigra subsp. endressii $(\mathrm{R})$, where the low number of populations $(\leq 3)$ precluded the validity of the significance tests (Table 3). Our dbRDA results showed a lack of significant correlation of Fis values with population genetic differentiation in all the analyzed cases, and thus only results from the marginal 
probability tests are shown. By contrast, they indicated that longitude significantly explained genetic differentiation between the $\mathrm{R}$ populations in $C$. jacea subsp. angustifolia (Table 3, Fig. 6A), whereas latitude showed a marginal significance, suggesting that populations might be genetically differentiated from east to west and, to a lesser extent, from north to south. Longitude also significantly explained the genetic differentiation of $\mathrm{R}$ versus NR populations of $C$. jacea subsp. angustifolia, C. debeauxii subsp. grandiflora $(\mathrm{R})$ versus subsp. debeauxii (NR), and C. linifolia $(\mathrm{R})$ versus $C$. stuessyi (NR), but not within morphotypes in $C$. debeauxii and C. linifolia-C. stuessyi (Table 3, Fig. 6B, D, and E, respectively). In C. nigra, latitude was the predictor variable that significantly explained the genetic differentiation of $\mathrm{R}$ versus $\mathrm{NR}$ populations (subsp. nigra and subsp. endressii) but not within them (Table 3, Fig. 6C). DbRDA analysis at the individual level also showed that Fis did not significantly affect the genetic differentiation of individuals in all studied cases and that geography significantly explained their differentiation within and between morphotypes (Supplementary Table S4).

Similarly, all Mantel tests performed at the individual level detected significant association between genetic and geographic distances within and between morphotypes (Supplementary Table S4, Supplementary Fig. $\mathrm{S} 2$ ). The predominantly linear trends of the $\mathrm{R}, \mathrm{NR}$, and $\mathrm{R}+\mathrm{NR}$ phenotypes in the IBD plots showed small slopes in most cases (Supplementary Fig. S2A; Fig. 2C, D) except for the Centaurea nigra subsp. endressii $\mathrm{R}$ trend line, where its pronounced slope clearly indicated that genetic differentiation increased with geographic distance for these phenotypes (Supplementary Fig. S2B). In C. jacea subsp. angustifolia, the linear trends of the $\mathrm{R}$ and $\mathrm{R}+\mathrm{NR}$ phenotypes overlapped, indicating that only geography explains the genetic differentiation of the morphs (Supplementary Fig. S2A). However, in the remaining cases (C. nigra, C. debeauxii, C. linifolia-C. stuessyi), the linear or curvilinear $\mathrm{R}+\mathrm{NR}$ trend showed slightly higher genetic distance values than the $R$ and NR trends (except that of $C$. stuessyi NR) (Supplementary Fig. S2B, S2C, S2D), suggesting that the floral morphotype, in addition to geography, could also contribute to the genetic differentiation of these morphs.

\section{Discussion}

GENETIC DIVERSITY, SPECIES BOUNDARIES, AND TAXONOMY OF IbERIAN CENTAUREA SECTS. JACEA AND LEPTERANTHUS GROUPS

The limited variability and resolution observed in previous plastid-based phylogenetic studies of Centaurea sects. Jacea and Lepteranthus (García-Jacas et al., 2006; Arnelas et al., 2018) suggested a recent evolutionary history for this group of Iberian knapweeds. However, our nuclear ribosomal internal transcribed spacer (ITS) region-based phylogeny demonstrated that despite the frequent hybridization detected between some taxa, a main split differentiated the lineages defined by sections Jacea and Lepteranthus (Arnelas et al., 2018). Our current AFLP study reinforces this hypothesis since we have recovered a clear genetic segregation of populations and taxa of Centaurea sects. Jacea and Lepteranthus (including C. gallaecica) in all the NJ phenogram, PCoA, STRUCTURE, and AMOVA analyses (Figs. 2, 3A, Table 2). Our molecular ITS and AFLP findings support our sectional classification (Arnelas \& Devesa, 2011, 2012; Devesa et al., 2014; Devesa, 2016). Additionally, our AFLP analysis corroborates the close relationships of species from both clades, reinforcing the hypothesis of the recent origin of the whole group. We have detected a small number of diagnostic and private fragments for sectional and infrasectional taxa (Table 1), and few mutational changes separating the short and poorly supported branches of the NJ phenogram (Fig. 2A). In general, our data revealed a high genetic structuring among populations $($ Fst $=0.59$; Table 2A), and no inter- or intraspecific admixed populations were observed in our NJ phenogram (Fig. 2A).

The higher among-population partition of variance found within Centaurea sect. Lepteranthus (65.44\%, Table 2 grouping D) rather than within Centaurea sect. Jacea (53\%, Table 2 grouping D) is presumably connected with geographic and eco-climatic diversification and adaptation, since all species from Centaurea sect. Lepteranthus are narrow endemics, whereas those from Centaurea sect. Jacea are more widespread taxa. Our genetic diversity study confirms that the more abundant and geographically widespread taxa of Centaurea sect. Jacea (C. debeauxii subsp. debeauxii, C. debeauxii subsp. grandiflora, C. jacea subsp. angustifolia, $C$. nigra subsp. nigra), together with one species of Centaurea sect. Lepteranthus $(C$. linifolia), possess the highest genetic variation values (Fig. 1, Table 1). These results are consistent with the hypothesis that larger populations are able to maintain higher levels of genetic diversity than smaller populations (Fischer \& Matthies, 1998; Gaudeul et al., 2000). The highest genetic DW values (Table 1) observed in rear-edge populations of widespread southwestern European taxa, such as $C$. jacea subsp. angustifolia, C. nigra, and C. debeauxii, might be related with their occurrence in northern Iberian glacial refugia, which likely maintained high genetic diversity levels in these southern peripherical populations (Hampe \& Petit, 2005; Nieto, 2011), and where new alleles could also have originated (Kimura, 1983). Our results showed the lowest genetic diversity values $(99 \% \mathrm{P}, h, \mathrm{Hs})$ for several endemic species of 
both Centaurea sections such as $C$. janeri subsp. janeri and $C$. janeri subsp. babiana, C. antennata subsp. antennata, and C. gallaecica (Table 1). Several studies have demonstrated that species with restricted distribution exhibit low genetic diversity (Piñeiro et al., 2009; Finlay et al., 2017). The DW values are low for $C$. nevadensis, C. janeri, and C. antennata subsp. antennata (Table 1) as expected for newly established populations (Schönswetter \& Tribsch, 2005). These results are in agreement with our previous estimations of the divergence of these narrow endemic taxa (Fig. 1) during the Pleistocene (1.3-2.2 million years ago [Ma], Arnelas et al., 2018).

The AFLP genetic structure and Fst data (Figs. 2, 3, Table 2) also support the hypothesis that geographic and ecological isolation in largely disjunct areas probably promoted rapid taxonomic diversification and allopatric speciation for these Iberian Centaurea taxa (Arnelas et al., 2018). In this sense, our PCoA and STRUCTURE analyses (Figs. 3E, 5D) demonstrated the segregation of C. gallaecica from C. janeri, a taxon to which the former species was previously subordinated. The divergence of these species was probably caused by spatial isolation after different founder events. Noticeably, our NJ phenogram (Fig. 2A) and STRUCTURE analysis showed close similarity between $C$. gallaecica and species of Centaurea sect. Lepteranthus in this study. However, in our taxonomic treatment of Centaurea sect. Lepteranthus (Arnelas \& Devesa, 2012), we treated C. gallaecica as part of Centaurea sect. Jacea based on the morphology of the bract appendages and the length of the pappus. This taxonomic decision was supported by our phylogenetic analysis of Centaurea sects. Jacea and Lepteranthus, which included a large number of species of Centaurea sect. Lepteranthus (Arnelas et al., 2018) and which placed $C$. gallaecica not within the Lepteranthus clade but within the Jacea I clade in the ITS tree. Thus, although our current AFLP data attribute C. gallaecica to Centaurea sect. Lepteranthus, we propose to maintain this species within Centaurea sect. Jacea until more species of Centaurea sect. Lepteranthus are analyzed genetically.

In our previous molecular study, we demonstrated the potential of Centaurea nigra s.l. and C. debeauxii s.l. to hybridize interspecifically, but also with $C$. jacea, though our phylogenetic data indicated that the three taxa could be considered different taxonomic entities (Arnelas et al., 2018). Our current AFLP study agrees with previous results, supporting their morphological segregations based on involucre shape, number of apical bract appendage fimbria, and length of pappus (Arnelas \& Devesa, 2011). Our study has further detected new relationships within Centaurea sects. Jacea and Lepteranthus. The NJ phenogram shows close similarity within most infraspecific ranks of Centaurea sect.
Jacea (C. nigra subsp. nigra and C. nigra subsp. endressii, C. debeauxii subsp. debeauxii, C. nevadensis) with only $C$. jacea subsp. angustifolia and $C$. debeauxii subsp. grandiflora showing dissimilarity (Fig. 2A). Similarities between $C$. jacea subsp. angustifolia (NR) and C. nigra subsp. endressii, and $C$. debeauxii subsp. grandiflora $(\mathrm{R})$ and $C$. nevadensis (NR and $\mathrm{R}$ ) were observed in the NJ phenogram (Fig. 2A), whereas the STRUCTURE plots showed moderate genetic introgressions in both groups (Fig. 4). In the STRUCTURE analysis, there is genetic connection of one population of C. debeauxii subsp. debeauxii (DNR 10) with C. nigra subsp. nigra and of one population of $C$. debeauxii subsp. grandiflora (DRA 06) with C. nigra subsp. endressii (Fig. 4C, D), suggesting potential gene flow among these taxa in the northern Iberian Peninsula. Some introgression is also apparent between $C$. debeauxii subsp. debeauxii and $C$. debeauxii subsp. grandiflora, with some populations of the former showing admixture with populations of the latter, and with a clear-cut genetic separation of $C$. nevadensis from both (Fig. 5A). Centaurea nevadensis also shows the highest genetic differentiation within Centaurea sect. Jacea, manifested in its largest $\mathrm{NJ}$ phenogram clade branch (Fig. 2A), and a considerable number of rare fragments in its $\mathrm{R}$ morphotype (Table 1$)$. These new results reinforce our taxonomic treatment (Arnelas \& Devesa, 2011) that recognized $C$. nevadensis as a separate species from C. debeauxii, in contrast to previous classification (Dostál, 1976). Centaurea nevadensis has accumulated a number of unique mutations that differentiate this taxon from its closest relatives, reinforced by its geographic isolation in southern Spain and potential ecological adaptation to warmer Pleistocene habitats, as indicated for other plant species (Pimentel et al., 2007; PérezCollazos et al., 2009). The low genetic diversity values obtained for this Ibero-Maghrebian endemic species with a restricted distribution in the Iberian Peninsula (Fig. 1) agree with several studies conducted in other endemic plant species where low genetic diversity is associated with founder events or genetic drift caused by fragmentation (Ellstrand \& Elam, 1993; Cruse-Sanders \& Hamrick, 2004).

Within Centaurea sect. Lepteranthus, our PCoA analysis demonstrated the segregation of $C$. linifolia- $C$. stuessyi, C. antennata subsp. antennata, C. janeri subsp. janeri and subsp. babiana, and C. gallaecica (Fig. 3E). The STRUCTURE analysis showed the overall separation of $C$. linifolia and $C$. stuessyi from $C$. gallaecica in the optimal $\mathrm{K}=2$ clustering (Fig. 5B) and three and five genetic groups, respectively, for $C$. stuessyi and $C$. linifolia with no intermixed taxa in a suboptimal $\mathrm{K}=8$ clustering (Fig. 5C). The PCoA and STRUCTURE analyses also confirmed the distinctness of C. gallaecica from C. janeri s.l. and C. antennata 
subsp. antennata (Figs. 3E, 5D). Overall, the AFLP data support the segregation of $C$. gallaecica and $C$. janeri, which also can be distinguished morphologically and cytotypically. The lowland northwestern Iberian $C$. gallaecica shows narrowly triangular and erect to erect-patent, not recurved, pectinate-fimbriate, and black involucral bract appendages, a short pappus ([0.1]0.3-0.5[0.9] mm), and $2 n=6 x=66$, whereas the montane central-western to northwestern Iberian $C$. janeri shows linear-subulate and recurved, pectinatefimbriate involucral brownish bract appendages, a longer pappus ([0.1]0.7-1.8[1.9] mm), and $2 n=4 x=44$ (Arnelas \& Devesa, 2010, 2012).

Speciation might also occur in the presence of gene flow if phylogenetic, karyological, and ecological divergence can be demonstrated (Chapman et al., 2013). It would explain the recent hybrid allopolyploid origin of the NR allotetraploid Centaurea stuessyi (Arnelas et al., 2013; 1.3 Ma, Arnelas et al., 2018) from its plausible diploid progenitors $C$. linifolia $(\mathrm{R})$ and $C$. antennata subsp. antennata $(\mathrm{NR})$, as evidenced in the NJ reconstruction and STRUCTURE plot (Figs. 2A, 5D). Our NJ phenogram, PCoA, and STRUCTURE analyses (Figs. 2A, 3E, 5B, and plastid phylogeny in Arnelas et al. 2018) support $C$. linifolia as the maternal progenitor. Support for $C$. antennata subsp. antennata as the paternal progenitor comes from the NJ phenogram, showing high similarity between this taxon and two populations of C. stuessyi (STU06, 02; Fig. 2A), and the STRUCTURE analysis (Fig. 5D), showing a high proportion of the $C$. antennata genetic profile in population STU 02 of $C$. stuessyi. These results suggest that the NR morphotype of $C$. stuessyi was probably acquired from $C$. antennata subsp. antennata, and that it may have separated from both parents by reproductive and geographical isolation. The genetic diversity values of $C$. stuessyi are higher than those of other species of Centaurea sect. Lepteranthus except C. linifolia. Several studies have corroborated an increasing trend in the genetic diversity of plant allopolyploids acquired through hybridization, though in other cases the genetic variation of the hybrid does not exceed that of the progenitor species (Marques et al., 2014).

GEOGRAPHY AND GENETIC ISOLATION OF $\mathbf{R}$ AND NR FLORAL MORPHOTYPES IN IBERIAN TAXa OF CENTAUREA SECTS. JaCEA AND LEPTERANTHUS

Our study has shown the plausible influence of geography in the genetic isolation of the $\mathrm{R}$ and NR morphotypes across the studied taxa and populations of Iberian Centaurea sect. Jacea and Lepteranthus (Table 3, Supplementary Table S4). Our distancebased redundancy analysis indicates that the inbreeding coefficient, taken as a surrogate of reproductive isolation, does not significantly explain the observed genetic differentiation of populations either within or between morphotypes (Table 3). By contrast, in all cases either the longitudinal ( $C$. jacea subsp. angustifolia, $C$. debeauxii subsp. debeauxii and subsp. grandiflora, $C$. linifolia-C. stuessyi) or latitudinal (C. nigra subsp. nigra and subsp. endressii) distribution of populations is significantly correlated with the genetic divergence of the R and NR morphs (Table 3, Fig. 6B, D-F). The fact that the population genetic differentiation is also explained by geography within the same morph in $C$. jacea subsp. angustifolia $\mathrm{R}$ (Table 3, Fig. 6A), but not in the other cases, implies that the spatial distance and isolation of populations within the same morph or between different morphs is probably the main factor causing their genetic differentiation (Table 3, Fig. 6B-E), even if the geographic distributions of the morphs could overlap partially (Fig. 1).

Spriggs et al. (2019) used linear models to suggest that genetic divergence between potential operational taxonomic units (OTUs) was significantly greater than what would be expected by geographic isolation alone using an individual sample-level approach. Our dbRDA and IBD analyses performed at individual level have demonstrated that geography is apparently the main factor explaining the genetic differentiation between and within floral morphotypes in Centaurea sects. Jacea and Lepteranthus (Supplementary Table S4). However, we cannot discount the possibility that other intrinsic or extrinsic factors, not represented by the inbreeding coefficient, may also have participated in the genetic isolation of the R and NR morphotypes. Indeed, the IBD plots showed that in C. nigra, C. debeauxii, and $C$. linifolia-C. stuessyi the combined R+NR morphotype trend lines displayed higher genetic distances than the separate R and NR lines (except C. stuessyi), suggesting that some floral morph-related factor(s) may also be contributing to the genetic differentiation of their respective individuals (Supplementary Fig. S2B-D). In fact, the AMOVA analysis detected an increase of genetic structure among groups with respect to taxonomic clustering (Table 2B) when intraspecific floral morphotypes are considered as different OTUs (Table 2C), indicating that for some taxa the floral morphs might have experienced separate diverging trends.

Gene flow explains the cohesiveness of species boundaries, whereas different biological and evolutionary factors (e.g., ecological adaptation, flowering phenology, pollination preference) constitute potential barriers to gene flow that promote speciation. Pollination has traditionally been considered a determinant of gene flow and a main factor driving speciation of several angiosperm lineages (Darwin, 1877). Floral traits can influence pollinator-mediated reproductive isolation 
between individuals, representing a direct link with microevolutionary processes (Caruso, 2006). Previous studies of the potential role of floral morphotypes in insect-mediated selection and reproductive success of Centaurea species indicated some preference of pollinators for the $\mathrm{R}$ morphotypes of $C$. scabiosa relative to the NR morphotypes of C. nigra (Lack, 1976). In light of our dbRDA and IBD data, which point to geography as the main factor explaining the genetic differentiation of R and NR morphotypes (Table 3, Supplementary Table S4, Fig. 6) and also to possible floral morph-related factor(s) (Supplementary Fig. S2B-D), we hypothesize that pollinator-mediated reproductive selection or an asyet unknown factor could have favored the fixation of different allelic regulators of the floral R/NR morphs promoting different evolutionary R and NR trends. This hypothesis is supported by the divergent trends of the $\mathrm{R}$ and NR floral morphs of $C$. jacea subsp. angustifolia with overlapping distribution ranges (Fig. 1A), as well as of morphs of $C$. nigra subsp. nigra-C. nigra subsp. endressii and $C$. debeauxii subsp. grandiflora-C. debeauxii subsp. debeauxii with partially overlapping ranges (Fig. 1B), as observed in the NJ phenogram (Fig. 2A) and PCoA (Fig. 3C, D) plots. These data suggest that the $\mathrm{R}$ and NR morphotypes of the 1.2-millionyears-old $C$. jacea subsp. angustifolia, 0.7- to 2.1million-years-old $C$. nigra, and 1.2- to 2.2-millionyears-old $C$. debeauxii (Arnelas et al., 2018) may have experienced allele fixation due to genetic drift at different times during the Quaternary. Studies in Senecio (Asteraceae) have demonstrated how recently evolved species are able to quickly transfer adaptive alleles to phylogenetically close species, thus promoting rapid divergence of the new evolutionary units (Chapman et al., 2013). More detailed evolutionary and biological reproductive studies are needed, however, to elucidate the potential role of population life history and pollinators in the evolutionary selection of floral morphs in the knapweeds.

In the only instance of allopatric R and NR morphs, found in Centaurea nevadensis (Fig. 1D), our analysis detected a segregation of them in the NJ phenogram, in which all the individuals clustered separately in their own R or NR morphotype group (Fig. 2A). By contrast, no segregation of $\mathrm{R}$ and NR morphs was observed in the PCoA (Fig. 3D) and STRUCTURE (Figs. 4C, 5A) plots. Thus, in C. nevadensis it is unclear whether the divergence of its $\mathrm{R}$ and NR populations could have been caused by the genetic isolation of the morphotypes or by their spatial isolation. In our taxonomic study of $C$. nevadensis in the Iberian Peninsula, we observed that the $\mathrm{R}$ morphotype was more abundant in central-eastern Spain, while the NR morphotype was restricted to southeastern Spain (Fig. 1D) (Arnelas \& Devesa, 2011). We hypothesize that the near fixation of the two floral forms in their allopatric geographical locations could have occurred recently, considering the relatively young age of the group (1.3-2.2 Ma; Arnelas et al., 2018), and that their genetic isolation is maintained by a large (ca. $400 \mathrm{~km})$ geographic barrier to gene flow. Moderate to high IBD values for other Iberian infraspecific plant taxa have also corroborated the occurrence of ongoing microevolutionary processes coupled with the expansion of different haplotype lineages (Martinez-Nieto et al., 2013).

\section{Literature Cited}

Anand, K. K., R. K. Srivastava, L. B. Chaudhary \& A. K. Singh. 2010. Delimitation of species of the Astragalus rhizanthus complex (Fabaceae) using molecular markers RAPD, ISSR and DAMD. Taiwania 55(3): 197-207.

Andersson, S. 2001. The genetic basis of floral variation in Senecio jacobea (Asteraceae). J. Heredity 92: 409-414.

Andersson, S. 2008. Pollinator and non-pollinator selection on ray morphology in Leucanthemum vulgare (oxeye daisy, Asteraceae). Amer. J. Bot. 95: 1072-1078. doi:10.3732/ ajb.0800087.

Arnelas, I. \& J. A. Devesa. 2010. Contribución al conocimiento cariológico de Centaurea L. (Asteraceae) en la Península Ibérica. Grupo Jacea-Lepteranthus. Lagascalia 30: 407-445.

Arnelas, I. \& J. A. Devesa. 2011. Revisión taxonómica de Centaurea sect. Jacea (Mill.) Pers. (Asteraceae) en la Península Ibérica. Acta Bot. Malac. 36: 33-88.

Arnelas, I. \& J. A. Devesa. 2012. Revisión taxonómica de Centaurea sect. Lepteranthus (Neck.) Dumort. (Asteraceae) en la Península Ibérica. Acta Bot. Malac. 37: 45-77.

Arnelas, I., J. A. Devesa \& E. López. 2013. Centaurea stuessyi (Compositae: Cardueae), a new species from the eastern Iberian Peninsula. Phytotaxa 115: 42-48. doi:10.11646/ phytotaxa.115.2.2.

Arnelas, I., E. Pérez-Collazos, J. A. Devesa, E. López \& P. Catalán. 2018. Phylogeny of highly hybridogenous Iberian Centaurea L. (Asteraceae) taxa and its taxonomic implications. Pl. Biosyst. 152(5): 1182-1190.

Bassam, B. J., G. Caetano-Anolles \& P. M. Gresshoff. 1991. Fast and sensitive silver staining of DNA in polyacrylamide gels. Anal. Biochem. 196: 80-83.

Caruso, C. M. 2006. The ecological genetics of floral traits. Heredity 97: 86-87.

Chapman, M. A., H. Leebens-Mack \& J. M. Burke. 2008. Positive selection and expression divergence following gene duplication in the sunflower CYCLOIDEA gene family. Molec. Biol. Evol. 25(7): 1260-1273.

Chapman, M. A. \& R. J. Abbott. 2009. Introgression of fitness genes across a ploidy barrier. New Phytol. 186: 63-71.

Chapman, M. A., S. Tang, D. Draeger, S. Nambeesan, H. Shaffer, J. G. Barb, S. J. Knapp, et al. 2012. Genetic analysis of floral symmetry in Van Gogh's sunflowers reveals independent recruitment of CYCLOIDEA genes in the Asteraceae. PLoS Genet. 8(3): E1002628. doi:10.1371/journal. pgen.1002628.

Chapman, M. A., S. J. Hiscock \& D. A. Filatov. 2013. Genomic divergence during speciation driven by adaptation to altitude. Molec. Biol. Evol. 30(12): 2553-2567.

Chybicki, I. J., A. Oleksa \& J. Burczyk. 2011. Increased inbreeding and strong kinship structure in Taxus baccata estimated from both AFLP and SSR data. Heredity 107(6): 589-600.

Coart, E., S. Van Glabekel, R. J. Petit, E. Van Bockstaele \& I. Roldán-Ruiz. 2005. Range wide versus local patterns of genetic diversity in hornbeam (Carpinus betulus L.). Conserv. Genet. 6: 259-273. 
Comes, H. P. 1998. Major gene effects during weed evolution: Phenotypic characters cosegregate with alleles at the ray floret locus in Senecio vulgaris L. (Asteraceae). J. Heredity 89: 54-61.

Cruse-Sanders, J. M. \& J. L. Hamrick. 2004. Genetic diversity in harvested and protected populations of wild American ginseng, Panax quinquefolius L. (Araliaceae). Amer. J. Bot. 91: 540-548.

Cubas, P. 2004. Floral zygomorphy, the recurring evolution of a successful trait. BioEssays 26(11): 1175-1184.

Darwin, C. 1877. The Various Contrivances by Which Orchids Are Fertilised by Insects. University of Chicago Press, Chicago.

Devesa, J. A. 2016. Las Especies del Género Centaurea en la Península Ibérica e Islas Baleares. Ucopress, Ediciones de la Universidad de Córdoba, Córdoba.

Devesa, J. A., E. López, I. Arnelas, V. N. Suárez-Santiago, G. Blanca, V. Rodriguez \& A. F. Muñoz-Rodríguez. 2014. Centaurea. Pp. 342-603 in S. Castroviejo, J. A. Devesa, A. Quintanar \& M. A. García (editors), Flora Iberica XVI. Real Jardín Botánico de Madrid CSIC, Madrid.

Dostál, J. 1976. Centaurea L. Pp. 254-301 in T. G. Tutin, V. H. Heywood, N. A. Burges, D. H. Valentine, S. M. Walters \& D. A. Webb (editors), Flora Europaea 4. Cambridge University Press, Cambridge.

Earl, D. A. \& B. M. vonHoldt. 2012. STRUCTURE HARVESTER: A website and program for visualizing STRUCTURE output and implementing the Evanno method. Conservation Genet. Res. 4: 359-361.

Ellstrand, N. C. \& D. R. Elam. 1993. Population genetic consequences of small population size: Implications for plant conservation. Annual Rev. Ecol. Syst. 24: 217-242.

Evanno, G., S. Regnaut \& J. Goudet. 2005. Detecting the number of clusters of individuals using the software STRUCTURE: A simulation study. Molec. Ecol. 14: 2611-2620.

Excoffier, L., G. Laval \& S. Schneider. 2005. Arlequin ver. 3.11: An integrated software package for population genetics data analysis. Evol. Bioinf. Online 1: 47-50.

Falush, D., M. Stephens \& J. K. Pritchard. 2003. Inference of population structure using multilocus genotype data: Linked loci and correlated allele frequencies. Genetics 164: 1567-1587.

Falush, D., M. Stephens \& J. K. Pritchard. 2007. Inference of population structure using multilocus genotype data: Dominant markers and null alleles. Molec. Ecol. Notes 7: 574-578.

Felsenstein, J. 1985. Confidence limits on phylogenies: An approach using the bootstrap. Evolution 39: 783-791.

Finlay, C. M. V., C. R. Bradley, S. J. Preston \& J. Provan. 2017. Low genetic diversity and potential inbreeding in an isolated population of alder buckthorn (Frangula alnus) following a founder effect. Sci. Rep. 7(1): 3010. doi:10.1038/s41598017-03166-1.

Fischer, M. \& D. Matthies. 1998. RAPD variation in relation to population size and plant fitness in the rare Gentianella germanica (Gentianaceae). Amer. J. Bot. 85: 811-819.

García-Jacas, N., A. Susanna, V. Mozaffarian \& R. Ilarslan. 2000. The natural delimitation of Centaurea (Asteraceae: Cardueae): ITS sequence analysis of the Centaurea jacea group. Pl. Syst. Evol. 223: 185-199.

García-Jacas, N., T. Uysal, K. Romaschenko, V. N. SuarezSantiago, K. Ertugrul \& A. Susanna. 2006. Centaurea revisited: A molecular survey of the Jacea group. Ann. Bot. (Oxford) 98(4): 741-753.

Gaudeul, M., P. Taberlet \& I. Till-Bottraud. 2000. Genetic diversity in an endangered Alpine plant, Eryngium alpinum L. (Apiaceae), inferred from amplified fragment length polymorphism markers. Molec. Ecol. 9: 1625-1637.

Gower, J. C. \& G. J. S. Ross. 1969. Minimum spanning tree and single linkage cluster analysis. Appl. Statist. 18: 54-64.
Hampe, A. \& R. J. Petit. 2005. Conserving biodiversity under climate change: The rear edge matters. Ecol. Lett. 8(5): 461-467.

Holsinger, K. E. \& P. O. Lewis. 2003. Hickory: A package for analysis of population genetic data v1.0 distributed by the authors. Department of Ecology and Evolutionary Biology, University of Connecticut, Storrs.

Holsinger, K., P. Lewis \& D. Dey. 2002. A Bayesian approach to inferring population structure from dominant markers. Molec. Ecol. 11: 1157-1164.

Huang, D., X. Li, M. Sun, T. Zhang, H. Pan, T. Cheng, J. Wang, et al. 2016. Identification and characterization of CYC-like genes in regulation of ray floret development in Chrysanthemum morifolium. Frontiers Pl. Sci. 7: 1633.

Ingram, R. \& L. Taylor. 1982. The genetic control of a nonradiate condition in Senecio squalidus L. and some observations on the role of ray florets in the Compositae. New Phytol. 91: 749-756.

Jackson, R. C. \& C. T. Dimas. 1981. Experimental evidence for systematic placement of the Haplopappus phyllocephalus complex (Compositae). Syst. Bot. 6: 8-14.

Kimura, M. 1983. The Neutral Theory of Molecular Evolution. Cambridge University Press, Cambridge.

Lack, A. J. 1976. Competition for pollinators and evolution in Centaurea. New Phytol. 91: 321-339.

Legendre, P. \& M. J. Fortin. 2010. Comparison of the Mantel test and alternative approaches for detecting complex multivariate relationships in the spatial analysis of genetic data. Molec. Ecol. Res. 10: 831-844.

Marques, I., D. Draper, L. Riofrío \& C. Naranjo. 2014. Multiple hybridization events, polyploidy and low postmating isolation entangle the evolution of neotropical species of Epidendrum (Orchidaceae). BMC Evol. Biol. 14: 20.

Martinez-Nieto, I., J. Segarra-Moragues, E. Merlo, F. MartinezHernández \& J. F. Poveda. 2013. Genetic diversity, genetic structure and phylogeography of the Iberian endemic Gypsophila struthium (Caryophyllaceae) as revealed by AFLP and plastid DNA sequences: Connecting habitat fragmentation and diversification. Bot. J. Linn. Soc. 173: 654-675.

Martínez-Ortega, M. M., L. Delgado, D. C. Albach, J. A. ElenaRossello \& E. Rico. 2004. Species boundaries and phylogeographic patterns in cryptic taxa inferred from AFLP markers: Veronica subgen. Pentasepalae (Scrophulariaceae) in the western Mediterranean. Syst. Bot. 29: 965-986.

Medrano, M., E. López-Perea \& C. M. Herrera. 2014. Population genetics methods applied to a species delimitation problem: Endemic trumpet daffodils (Narcissus section Pseudonarcissi) from the southern Iberian Peninsula. Int. J. Pl. Sci. 175(5): 501-517.

Nei, M. \& W. H. Li. 1979. Mathematical model for studying genetic variation in terms of restriction endonucleases. Proc. Natl. Acad. Sci. U.S.A. 186: 5269-5273.

Nieto, G. 2011. Southern European glacial refugia: A tale of tales. Taxon 60(2): 365-372.

Oksanen, J., F. G. Blanchet, M. Friendly, R. Kindt, P. Legendre, D. McGlinn, P. R. Minchin, et al. 2019. VEGAN: 623 Community Ecology Package. $\mathrm{R}$ package version 2.56. <https://cran.r-project.org/web/packages/vegan/index.html>, accessed 28 October 2020.

Pérez-Collazos, E. \& P. Catalán. 2006. Palaeopolyploidy, spatial structure and conservation genetics of the narrow steppe plant Vella pseudocytisus subsp. paui (Vellinae, Cruciferae). Ann. Bot. (Oxford) 97: 635-647.

Pérez-Collazos, E., P. Sánchez-Gómez, J. F. Jiménez \& P. Catalán. 2009. The phylogeographical history of the Iberian steppe plant Ferula loscosii (Apiaceae): A test of the abundant-centre hypothesis. Molec. Ecol. 18: 848-861. 
Petit, R. J., A. El Mousadik \& O. Pons. 1998. Identifying populations for conservation on the basis of genetic markers. Conserv. Biol. 12(4): 844-855.

Pimentel, M., E. Sahuquillo \& P. Catalán. 2007. Genetic diversity and spatial correlation patterns unravel the biogeographical history of the European sweet vernal grasses (Anthoxanthum L., Poaceae). Molec. Phylogen. Evol. 44: 667-684.

Piñeiro, R., J. Fuertes, M. Menezes \& G. Nieto. 2009. Low genetic diversity in the rare Madeiran endemic Armeria maderensis (Plumbaginaceae). Folia Geobot. Phytotax. 44: 65-81.

Pritchard, J. K. \& W. Wen. 2004. Documentation for Structure Software: Version 2. University of Chicago, Chicago.

Pritchard, J. K., M. Stephens \& P. Donnelly. 2000. Inference of population structure using multilocus genotype data. Genetics 155: 945-959.

R Core Team. 2019. R: A language and environment for statistical computing. R Foundation for Statistical Computing, Vienna, Austria. <https://www.R-project.org/>, accessed 28 October 2020.

Rohlf, F. J. 2002. NTSYS pc. Numerical Taxonomy and Multivariate Analysis System. Version 2.1 la. Exeter Software, New York.

Saitou, N. \& M. Nei. 1987. The neighbor-joining method: A new method for reconstructing phylogenetic trees. Molec. Biol. Evol. 4(4): 406-425.

Schönswetter, P. \& A. Tribsch. 2005. Vicariance and dispersal in the alpine perennial Blupeurum stellatum L. (Apiaceae). Taxon 54(3): 725-732.
Spriggs, E. L., D. A. Eaton, P. W. Sweeney, C. Schlutius, E. J. Edwards \& M. J. Donoghue. 2019. Restriction-siteassociated DNA sequencing reveals a cryptic Viburnum species on the North American coastal plain. Syst. Biol. 68(2): 187-203.

Stuessy, T. F., D. M. Spooner \& K. A. Evans. 1986. Adaptive significance of ray corollas in Helianthus grosseserratus (Compositae). Amer. Midl. Naturalist 115: 191-197.

Susanna, A. \& N. García-Jacas. 2007. Tribe Cardueae. Pp. 123-147 in J. W. Kadereit \& C. Jeffrey (editors), The Families and Genera of Vascular Plants. Springer, Berlin, Heidelberg.

Tremetsberger, K., S. Talavera, T. F. Stuessy, M. AngelesOrtiz, H. Weiss- Schneeweiss \& G. Kadlec. 2004. Relationship of Hypochaeris salzmanniana (Asteraceae, Lactuceae), an endangered species in the Iberian Peninsula, to $H$. radicata and $H$. glabra and biogeographical implications. Bot. J. Linn. Soc. 146: 79-95.

Trow, A. H. 1912. On the inheritance of certain characters in the common groundsel-Senecio vulgaris $\mathrm{L}$. and its segregates. J. Heredity 2: 239-276.

Vos, P., R. Hogers, M. Bleeker, M. Reijans, T. Van de Lee, M. Hornes, A. Frijters, et al. 1995. AFLP: A new technique for DNA finger-printing. Nucl. Acids Res. 23: 4407-4414.

Willkomm, H. M. 1865. Centaurea. Pp. 138-169 in H. M. Willkomm \& J. M. Ch. Lange (editors), Prodromus Florae Hispanicae 2. E. Schweizerbart, Stuttgart.

Wright, S. 1951. The genetical structure of species. Ann. Eugenics 15: 323-354. 